\title{
Trends in concentrations of atmospheric gaseous and particulate species in rural eastern Tennessee as related to primary emission reductions
}

\author{
R. L. Tanner ${ }^{1, *}$, S. T. Bairai ${ }^{1, a}$, and S. F. Mueller ${ }^{1, b}$ \\ ${ }^{1}$ Tennessee Valley Authority, P.O. Box 1010, Muscle Shoals, Alabama, USA \\ anow at: Battelle, Pueblo, Colorado, USA

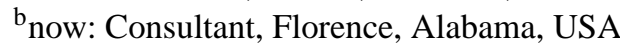 \\ * retired
}

Correspondence to: S. F. Mueller (sfm-ccm@att.net)

Received: 10 March 2015 - Published in Atmos. Chem. Phys. Discuss.: 6 May 2015

Revised: 5 August 2015 - Accepted: 12 August 2015 - Published: 1 September 2015

\begin{abstract}
Air quality measurements at Look Rock, Tennessee - on the western edge of the Great Smoky Mountains National Park - were begun in 1980 and expanded during the 1980s to a National Park Service (NPS) IMPROVE network station. Measurements were expanded again by the Tennessee Valley Authority (TVA, 1999-2007) to examine the effects of electric generating unit (EGU) emission reductions of $\mathrm{SO}_{2}$ and $\mathrm{NO}_{x}$ on air quality at the station. Analysis of temporal trends (1999-2013) has been conducted at the site in collaboration with activities related to the 2013 Southeast Atmosphere Study (SAS) at Look Rock and other southeastern US locations.

Key findings from these trend studies include the observation that primary pollutant levels have consistently tracked emission reductions from EGUs and other primary sources in the region, but reductions in secondary pollutants such as particulate sulfate and, specifically, ozone have been smaller compared to reductions in primary emissions. Organic carbonaceous material (OM) remains a major contributor (30$40 \%$ in the period 2009-2013) to fine particulate mass at the site, as confirmed by ACSM measurements at the site in 2013. A large portion (65-85\%) of carbon in OM derives from modern carbon sources based on ${ }^{14} \mathrm{C}$ measurements. Important parameters affecting ozone levels, fine mass, and visibility also include the specific diurnal meteorology at this ridge-top site, its location in a predominantly mixeddeciduous forest, and the presence of primary sources of precursors at distances of $50-500 \mathrm{~km}$ from the site in all directions.
\end{abstract}

\section{Introduction}

Observations in and near the Great Smoky Mountains National Park (GSMNP) have been included in many air quality trend analyses for national parks (e.g., Cai et al., 2011; Cooper et al., 2014; U.S National Park Service, 2013). Despite its rural location, the GSMNP is near enough to major urban centers (e.g., Knoxville, TN; Chattanooga, TN; Birmingham, AL; Atlanta, GA) and other areas of high air emissions (e.g., Ohio River and Tennessee River valleys) that it represents a guidepost for tracking the progress and benefits of various air pollution regulatory actions throughout recent history (e.g., acid rain emission reductions, regional $\mathrm{NO}_{x}$ reductions for ozone control). Also, an era of low natural gas prices has made switching from coal to natural gas very attractive to power producers facing the latest regulatory pressures (U.S. Energy Information Administration, 2014), and these actions have triggered further downward movement in emissions of both sulfur dioxide and nitrogen oxide that play a large role in determining air quality over the GSMNP. The deployment of a state-of-the-art monitoring system for aerosol chemical speciation at the GSMNP Look Rock monitoring site in 2013 (Budisulistiorini et al., 2015) offers a new opportunity to revisit air quality in the GSMNP with a specific focus on aerosol composition. The 2013 deployment of an Aerodyne aerosol chemical speciation monitor (ACSM) - with the ability to investigate the composition of organic aerosol mass (abbreviated here as organic mass, or "OM") makes it especially useful to understand the extent to which 
the air pollutant matrix over the region has changed since about 2000. This paper examines recent air quality trends at Look Rock to enable researchers to place the 2013 data in proper perspective.

The Look Rock air quality research station in the GSMNP is located in a forest opening on the ridge line of Chilhowee Mountain. This elongated mountain oriented southwestnortheast borders the eastern edge of the Tennessee River valley. The ridge top lies $400-500 \mathrm{~m}$ above the valley floor, while much higher mountains of the Great Smoky Mountains are found to the east and south. Chilhowee Mountain is mostly covered by mixed deciduous forest and has been forested for decades. Although low-density single-family housing lies in valleys on either side of the site, its impact on gaseous and particulate concentrations at the site is infrequent and usually small because of its elevation well below the monitoring site.

Look Rock has been the site of an IMPROVE network (Hand, 2011) station - designated GRSM1 - and operated by the U.S. National Park Service (NPS) since the 1980s. Activities at the site have included intensive research studies (e.g., SEAVS; Day et al., 1996) in addition to long-term IMPROVE network monitoring. The Tennessee Valley Authority (TVA) - in collaboration with the NPS - added continuous measurements of gases in 1999 to complement periodic intensive studies during which aerosol composition was measured with a time resolution of $<24 \mathrm{~h}$ (Cheng and Tanner, 2002; Tanner et al., 2005). Continuous measurements of fine mass, sulfate, nitrate, and aerosol carbon were also conducted in 2003-2004 with the sponsorship of a regional air management planning organization with the acronym "VISTAS" ("Visibility Improvement State and Tribal Organization of the Southeast") and described in Brewer and Moore (2009). Other analyses of Look Rock data addressed the seasonal and diurnal variability of aerosol composition and levels of precursor gases (Tanner et al., 2004b, 2005), the role of aerosol acidity, and meteorology on observed inorganic and organic aerosol levels (Olszyna et al., 2005), and identification of the contribution of biogenic volatile organic compound (BVOC) sources to aerosols based on ${ }^{14} \mathrm{C}$ measurements from filtrated ambient air (Tanner et al., 2004a).

Subsequent advances in continuous measurement techniques for gases and aerosol constituents led to enhanced measurement capabilities at the site beginning in late 2006 . With support from the Tennessee Department of Environmental Conservation (TDEC) and the U.S. Environmental Protection Agency (EPA), Look Rock was further instrumented (see Table 1) and designated a rural NCore network station effective 1 January 2011. In addition to the continuous measurements listed in Table 1, measurements of hourly aerosol organic and elemental carbon levels have been made beginning in April 2011. Routine, continuous monitoring of aerosol mass, sulfate, black carbon, and primary and secondary gases - supplemented by enhanced measurements during a series of intensive research studies - has produced a unique and comprehensive air quality database on background levels of species relevant to National Ambient Air Quality Standards (NAAQS) for ozone and particulate matter for a high-elevation site in the southeastern US.

Currently, special studies at the site include the deployment of an ACSM as described by Budisulistiorini et al. (2015), who also describe other measurements made to accompany the aerosol data from the ACSM from February 2013 to January 2014. An expanded research campaign was conducted from 1 June to 15 July 2013 in conjunction with the regional Southern Oxidant and Aerosol Study (SOAS) and the related SENEX and NOMADSS airborne campaigns, all a part of the Southeast Atmosphere Study (SAS) (UCAR, 2014/https://www.eol.ucar.edu/ field_projects/sas; U.S. National Oceanic and Atmospheric Administration, NOAA, 2013; Southeast Nexus, SENEX: Studying the Interactions between Natural and Anthropogenic Emissions at the Nexus of Air Quality and Climate Change, Boulder, CO: NOAA/http://www.esrl.noaa.gov/csd/ projects/senex/; EPA, 2014/http://blog.epa.gov/science/tag/ southern-atmosphere-study-sas). A review of the existing surface database is critically needed in light of an explosion of recent mechanistic studies of sources of organic particles, their relation to precursor anthropogenic and BVOC emissions, and the role of these emissions in the formation and accumulation of ambient secondary organic aerosol (Hallquist et al., 2009; Surratt et al., 2010; Hoyle et al., 2011; Shilling et al., 2013).

A comprehensive review is presented here of air quality trends at the Look Rock site covering its period as an IMPROVE station, during periodic TVA activities from 1999 to 2007, and after expanded continuous measurements were begun in 2007. This period is characterized as one during which precursor emissions of species contributing to $\mathrm{PM}_{2.5}$ mass were being reduced throughout the region. The following expands on analyses of visibility and ozone trends that have been conducted using the site's long-term IMPROVE aerosol, light scattering, and gaseous database (Hand et al., 2012; http://vista.cira.colostate.edu/improve/ Overview/Overview.htm). The objectives of this review are threefold. First, this review determines the existence of significant trends since 1999 in air emissions and air pollutant (including aerosol) precursors, as well as associated changes in secondary air quality variables. Second, this study examines the degree to which changes in emissions (of $\mathrm{SO}_{2}, \mathrm{NO}_{x}$, and other species in the region) are associated with reductions in ambient levels of secondary gaseous and particulate species. Finally, this effort uncovers the extent to which changes in meteorological parameters may influence pollutant trends. 
Table 1. Routine instrumentation deployed at Look Rock.

\begin{tabular}{|c|c|c|c|c|c|}
\hline Agency responsible & Species & Averaging time & Method & Instrument & MDA \\
\hline TVA & $\mathrm{NO}-\mathrm{NO}_{y}$ & $1 \mathrm{~h}$ & $\begin{array}{l}\text { Chemilum. w/ Mo } \\
\text { converter }\end{array}$ & Thermo model 42c & $\begin{array}{l}\mathrm{NO}: 0.1 \mathrm{ppbv} \\
\mathrm{NO}_{y}: 0.2 \mathrm{ppbv}\end{array}$ \\
\hline TVA & $\mathrm{NO}_{2}-\mathrm{NO}_{x}$ & $1 \mathrm{~h}$ & $\begin{array}{l}\text { Chemilum. w/ } \\
\text { photolytic converter }\end{array}$ & $\begin{array}{l}\text { Teledyne model 200EU } \\
\text { (trace level) }\end{array}$ & $\mathrm{NO}_{2}: 0.2 \mathrm{ppbv}$ \\
\hline TVA & $\mathrm{CO}$ & $1 \mathrm{~h}$ & NDIR-GFC & Thermo model 48i TLE & $50 \mathrm{ppbv}$ \\
\hline TVA & $\mathrm{PM}_{2.5} \mathrm{BC}$ & $1 \mathrm{~h}$ & $\begin{array}{l}\text { Optical absorption } \\
\text { on filter tape }\end{array}$ & $\begin{array}{l}\text { Magee Sci. model AE } \\
21 \text { Aethelometer } \\
\text { (dual-beam BC/UV) }\end{array}$ & $0.075 \mu \mathrm{g} / \mathrm{m}^{3}$ \\
\hline TVA & $\mathrm{PM}_{2.5} \mathrm{OC}$ and $\mathrm{EC}$ & $1 \mathrm{~h}$ & $\begin{array}{l}\text { Thermal-optical } \\
\mathrm{CO}_{2} \text { NDIR }\end{array}$ & $\begin{array}{l}\text { Sunset Lab. semi- } \\
\text { continuous org./elem. } \\
\text { field carbon aerosol } \\
\text { analyzer }\end{array}$ & $\begin{array}{l}\text { OC: } 0.25 \mu \mathrm{g} / \mathrm{m}^{3} \\
\text { EC: } 0.05 \mu \mathrm{g} / \mathrm{m}^{3}\end{array}$ \\
\hline NPS & $\mathrm{PM}_{2.5}$ aerosol mass & $1 \mathrm{~h}$ & TEOM & Thermo/R\&P & $\mathrm{PM}_{2.5}:<1 \mu \mathrm{g} / \mathrm{m}^{3}$ \\
\hline NPS-IMPROVE & $\mathrm{PM}_{2.5}$ aerosol mass & $\begin{array}{l}24 \text { h every 3rd day, } \\
\text { denoted " } 24 / 3 \text { " }\end{array}$ & Filter pack & Gravimetry & $\begin{array}{l}\text { See IMPROVE } \\
\text { data protocols }\end{array}$ \\
\hline NPS-IMPROVE & $\begin{array}{l}\text { Sulfate/nitrate/ammonium } \\
\text { /chloride mass }\end{array}$ & $24 / 3$ & Filter pack & $\begin{array}{l}\text { Ion chromatography/wet } \\
\text { chemistry }\end{array}$ & \\
\hline NPS-IMPROVE & $\begin{array}{l}\mathrm{PM}_{2.5} \text { elemental } \\
\text { composition }\end{array}$ & $24 / 3$ & PIXE \& XRF & - & \\
\hline NPS-IMPROVE & $\mathrm{PM}_{10}$ aerosol mass & $24 / 3$ & Filter pack & Gravimetry & \\
\hline NPS & $b_{\mathrm{abs}}$ & $24 / 3$ & Filter pack & Optical absorption & \\
\hline NPS & $b_{\mathrm{sp}}$ & $1 \mathrm{~h}$ & Light scattering & Nephelometer & \\
\hline NPS-CASTNET & $\begin{array}{l}\text { Temp., RH, wind speed } \\
\& \text { dir. }(\Theta), c_{W} \& \text { UV }\end{array}$ & $1 \mathrm{~h}$ & Various & - & \\
\hline
\end{tabular}

\section{Analysis methods}

\subsection{Emissions in domain of influence}

A domain of highest potential impact from primary emissions on Look Rock air quality was defined to evaluate the effects of changes in emissions on air quality at the site. This domain (Fig. 1) included most of Tennessee and Kentucky; portions of northern Alabama and northern Georgia (including the Atlanta metropolitan area); and western portions of South Carolina, North Carolina (including the Charlotte area), and Virginia. This "Look Rock emissions region" was essentially an ellipse containing Look Rock and was $500 \mathrm{~km}$ along the longest (roughly west-east) axis. The region was slightly skewed westward to account for prevailing winds. The intent was to define an area in which changes in emissions of primary species could be expected to cause the highest changes in concentrations of these and associated secondary species at Look Rock with transport times of the order of 1-2 days at most (i.e., shorter in winter, when winds are greater, and longer in summer when, winds are lighter and atmospheric chemistry is more active). It is likely that Look Rock concentrations of secondary species such as sulfate aerosol do not respond proportionately to changes in precursor levels within the defined emission region.

Emissions data were obtained at the state level from the EPA as part of the National Emissions Inventory (NEI) for each year from 1999 through 2013. These data are summarized online at http://www.epa.gov/ttnchie1/trends/. Countywide emissions were taken from NEI inventories released by EPA for 1999, 2002, 2005, 2008, and 2011. Electrical generating unit (EGU) emissions were also obtained for $\mathrm{SO}_{2}$ and $\mathrm{NO}_{x}$ for the domain on an annual basis over this period (http://ampd.epa.gov/ampd/QueryToolie.html). Graphs of the NEI results (Fig. 2a and b) show moderate downward trends in emissions - trends that accelerated for $\mathrm{NO}_{x}$ and $\mathrm{SO}_{2}$ in the period between 2008 and 2011. Data files obtained for the $1999 \mathrm{NEI}$ inventory were incomplete for $\mathrm{CO}$, $\mathrm{NH}_{3}, \mathrm{NO}_{x}$, and VOCs (volatile organic compounds) for unknown reasons, and both primary PM categories (PM10-PRI and PM2.5-PRI) are not shown. Also, county-level and EGU data for 2013 were not available at the time this analysis was started, so total domain emissions were extrapolated from 2012 data and the 2013 state-level EGU : total emission ratio in the NEI database. The NEI data for total $\mathrm{SO}_{2}$ emis- 


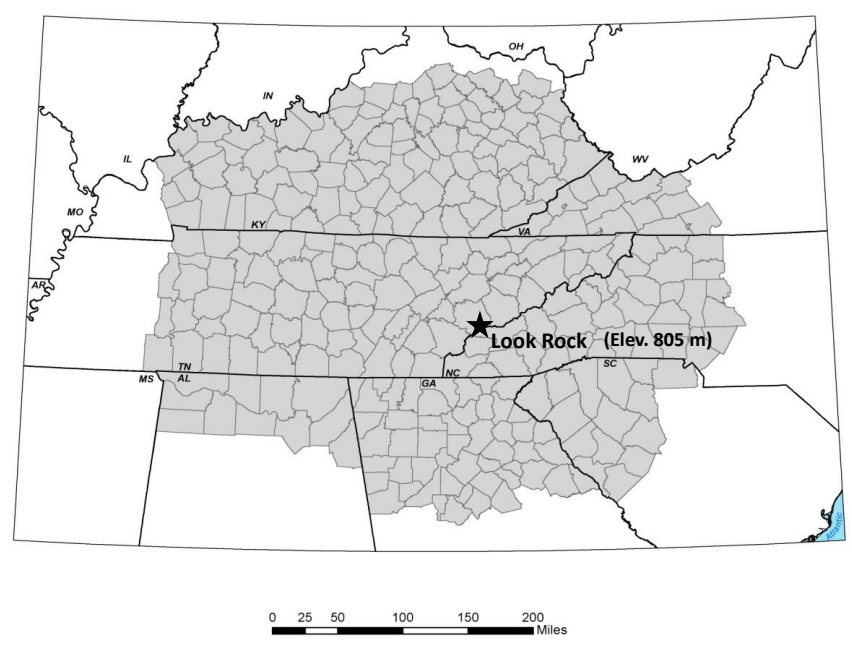

Figure 1. Spatial domain used to compare trends in air quality with trends in emissions of precursor species.

sions (Fig. 2b) are consistent with trends in the EGU data. Total regional $\mathrm{NO}_{x}$ emissions (Fig. 2b) are likely to be a better predictor of Look Rock ozone than $\mathrm{EGU} \mathrm{NO}_{x}$ emissions. For subsequent statistical analysis, the annual variation in total $\mathrm{NO}_{x}$ emissions was estimated using the annual EGU $\mathrm{NO}_{x}$ emissions and the ratio between EGU and non-EGU $\mathrm{NO}_{x}$ emissions determined when data from both were available at the county level. Interpolation of this ratio (from a proportional comparison with the annual state-wide ratios) to other years was done to estimate total $\mathrm{NO}_{x}$ within the Look Rock domain for years without a detailed county-level inventory. The EGU : total $\mathrm{SO}_{2}$ emissions ratio decreased from 75 to $51 \%$ over the 15 -year interval. The $\mathrm{NO}_{x}$ emissions ratio decreased from 34 to 12 percent over the same time frame.

\subsection{Techniques and data sources for gases and aerosols}

The filter-based and continuous measurements made at Look Rock are listed in Table 1 and represent methodologies used since 2007. The starting dates for the NPS vary from the 1980s for IMPROVE filter measurements through about 2002 when the TEOM (tapered element oscillating microbalance) instrument was installed. IMPROVE filter-based ammonium data are available beginning in 1998. Concentration data for gases $-\mathrm{SO}_{2}, \mathrm{NO}-\mathrm{NO}_{2}-\mathrm{NO}_{y}, \mathrm{CO}$ and $\mathrm{O}_{3}-$ and for aerosol mass and chemical constituents (sulfate, organic carbon (OC), elemental carbon (EC), or black carbon (BC)) were acquired for the period from 1999 to 2013 for all time periods in which there were continuous records from which valid annual, seasonal, and monthly data could be calculated.

Data for $\mathrm{SO}_{2}$ at Look Rock are from several sources including the CASTNET station at Look Rock, short-term campaign hourly data, and continuous $\mathrm{SO}_{2}$ data (reported as $1 \mathrm{~h}$ averages) acquired since March 2007 as part of the long-term monitoring initiative. Continuous hourly averaged
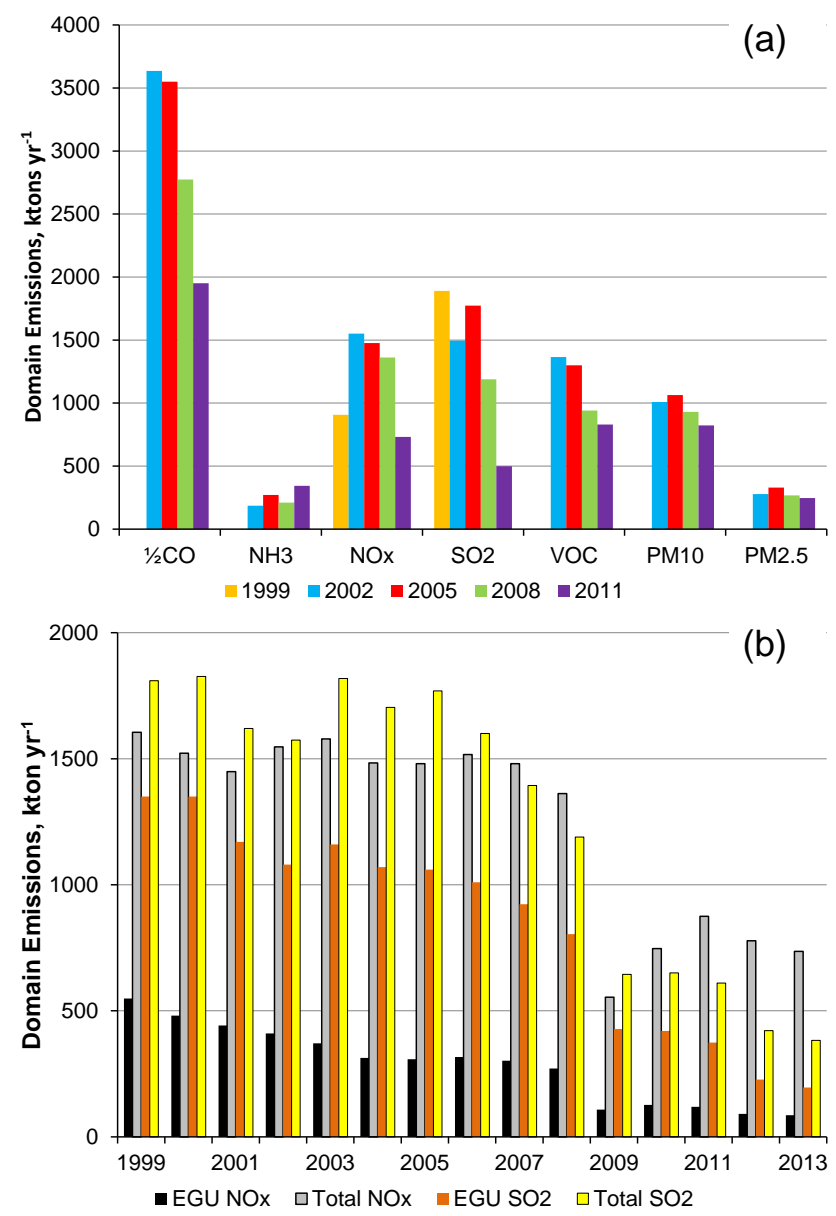

Figure 2. (a) NEI emissions by species within the Look Rock domain for select years between 1999 and 2011 (data other than $\mathrm{SO}_{2}$ and $\mathrm{NO}_{x}$ were not considered reliable for 1999 and are not shown). (b) Yearly $\mathrm{NEI} \mathrm{SO}_{2}$ and $\mathrm{NO}_{x}$ emissions - EGU and all sources within the Look Rock domain for 1999-2013.

data examined in the trend analyses below included sulfate, $\mathrm{SO}_{2}$, and $\mathrm{NO}-\mathrm{NO}_{y}$ data from previous studies (e.g., VISTAS 2003 and 2004, and summer research intensive studies) at the site, and used the same instruments or earlier prototypes as listed in Table 1. Organic and total aerosol carbon were measured from April 2003 through the end of 2004 by the R\&P model 5400 analyzer. OC and EC data obtained since April 2011 were obtained using a Sunset Laboratory OCEC analyzer (Birch and Cary, 1996; Bae et al., 2004). The annual average data for OC and EC at the site were obtained from every-third-day or twice-weekly $24 \mathrm{~h}$ filter samples analyzed by the IMPROVE TOR method (Chow et al., 1993). Measurement methods, detection limits, instrument characteristics and instrument calibration procedures are consistent with EPA data quality assurance requirements as outlined in EPA NCore network strategy (National Ambient Air Monitoring Strategy: http://www.epa.gov/ttn/amtic/files/ambient/ monitorstrat). The IMPROVE TEOM PM 2.5 mass had to be 
corrected to adjust for the fact that the NPS operated the TEOM from the beginning at $30^{\circ} \mathrm{C}$ but used the calculation algorithm originally designed for operation at $50^{\circ} \mathrm{C}$. To avoid bias in reported mass (the lower temperature better preserves ammonium nitrate and some semi-volatile OC) compared with standard filter-based $\mathrm{PM}_{2.5}$ data, TEOM values were corrected based on an algorithm developed to produce results which were highly correlated with reported Federal Reference Method (FRM) $\mathrm{PM}_{2.5}$ mass with essentially zero intercept.

Annual quarters 1 (January-March), 2 (April-June), 3 (July-September), and 4 (October-December) were defined as winter, spring, summer, and fall, respectively, for determining seasonal data trends for investigating meteorological influences. The approach allows for spring and summer to be consistently the periods with highest temperature $(T)$, solar radiation, and leaf coverage, while fall and winter have lower $T$ and solar radiation and very little deciduous leaf cover. Major differences in trends are unlikely when compared to seasonal data binned according to solstice and equinox dates or using alternate definitions such as winter as DecemberFebruary.

\subsection{Influence of meteorological patterns}

Temporal patterns in meteorology may influence Look Rock air quality due to the dependence of atmospheric chemistry and pollutant transport on variations in temperature, solar radiation, cloud cover, precipitation, and wind patterns. Patterns were based on data collected at Look Rock and the nearest National Weather Service (NWS) observations at the Knoxville airport. Data from these two sites are described in the Supplement. A few significant (i.e., >95\% confidence) trends were identified over the time period from 1999 through 2013.

Atmospheric transport was inferred from computed threedimensional air trajectories. Twenty-four hour air trajectories ending at Look Rock were computed using the NOAA HYSPLIT model (www.arl.noaa.gov/HYSPLIT_info.php; Draxler and Hess, 1998; Draxler, 1999; Draxler and Rolph, 2014). Trajectories were based on the NOAA-NCAR Global Reanalysis meteorological data set and used diagnosed vertical velocity to determine vertical air parcel motion. Trajectories were derived for days when TEOM data indicated fine particulate levels in either the lowest or highest $5 \%$ of the distribution of all hourly $\mathrm{PM}_{2.5}$ concentrations in each month. This ensured that the various trajectory classes contributed to the full range of particulate levels at Look Rock. Two or more trajectory analysis days were selected monthly during 2007-2013 (ending in June of 2013), yielding a data set of 174 trajectories. Trajectories were computed to arrive at 100,500 , and $1500 \mathrm{~m}$ above Look Rock at local midnight on the trajectory analysis days. Trajectories arriving at $1500 \mathrm{~m}$ a.g.l. were so similar to those for $500 \mathrm{~m}$ that they pro- vided little additional information and were not included in a subsequent cluster analysis.

Cluster analysis is a useful aggregation tool for classifying data into groups with similar locations in $K$-dimensional space (Wilks, 2006). Hourly upwind trajectory coordinates were available for each combination of trajectory arrival date and trajectory height. Trajectory latitude and longitude coordinates at 12 and $24 \mathrm{~h}$ upwind and at 100 and $500 \mathrm{~m}$ arrival heights were the focus of a cluster analysis designed to identify similar atmospheric transport pathways approaching Look Rock. In this case, $K=2$ and spatial coordinates were defined using latitude and longitude transformed into orthogonal variables with unit variance and mean of zero. The transformation was made using principal component analysis (Preisendorfer, 1988) for each upwind time.

Cluster analysis yielded groupings (clusters) of trajectories that represented the full range of $5 \mathrm{~h}$ average $\mathrm{PM}_{2.5}$ concentrations centered on daily minimum or maximum hourly values. Cluster $\mathrm{PM}_{2.5}$ averages showed a wide range of values, suggesting that each cluster represented a unique set of characteristics due to different combinations of trajectory geography and speed. Temporal trends (2007-2013) within clusters were computed when possible, and these trends were arbitrarily sorted into three groups based on mean $\mathrm{PM}_{2.5}$ values (low $\left(<10 \mu \mathrm{g} \mathrm{m}^{-3}\right)$, medium $\left(10-20 \mu \mathrm{g} \mathrm{m}^{-3}\right)$, and high $\left(>20 \mu \mathrm{g} \mathrm{m}^{-3}\right)$ ). Significant trends were only computable for the largest clusters because they had sufficiently large numbers of trajectory days and represented years. Even so, trend values for individual clusters are not as important as cluster trends sorted by $\mathrm{PM}_{2.5}$ concentration groupings. A comparison across $\mathrm{PM}_{2.5}$ groups indicated that temporal trends were significant and downward only for clusters that fell into the high-PM $\mathrm{P}_{2.5}$ group. In the subsequent discussion, the trajectory cluster number refers to the hierarchy of clusters starting with the cluster (assigned a value of 1) having the most trajectories for which some predetermined criteria are met that define a property of the trajectories. In the present study, Ward's method of in-cluster variance minimization was used (Wilks, 2006). Subsequent (lower number) clusters have fewer trajectories. Clusters are built starting with each trajectory in its own cluster and aggregating trajectories on subsequent passes through the data. This process can continue only until all trajectories are clustered into one group (such an endpoint has no value, however). The analyst must select some number of clusters $>1$ for which the highest ranked clusters contain a useful amount of trajectories that are classified. Once a trajectory is placed into a cluster it is not removed.

\subsection{Trend determination}

In the subsequent discussion, a determination of "significance" when evaluating the presence of a trend, when comparing changes in emissions and air pollutant concentrations, or when comparing air quality and meteorology was based 
on a statistical association computed (using least-squares regression) to have a $p$ value $<0.05$. Temporal changes in both domain-wide annual $\mathrm{NO}_{x}$ and $\mathrm{SO}_{2}$ emissions (all sources) were significant with $p<0.001$ (i.e., confidence exceeding $99.9 \%$ ). Seasonal emissions were not estimated (seasonal emissions for non-EGU sources must be modeled and this adds another level of complexity and uncertainty to the trend analysis). Trends in total seasonal emissions are expected to be similar to annual trends, with some seasons experiencing more changes than others depending on the timing of specific regulatory drivers. This assumption of similarity is used in all subsequent comparisons between seasonal air quality values and emissions and contributes to uncertainty when comparing them. The convention for comparing emissions, air quality, and meteorological values averaged over time (annual or seasonal) involved converting actual values into deviations from the 15-year average and then normalizing the deviation by the standard deviation of the 15 -year value:

$\hat{x}=\frac{x-\bar{x}}{\sigma_{x}}$,

where the overbar denotes the multi-year average of variable $x$, while $\sigma_{x}$ denotes its corresponding standard deviation. This scaling of $x$ reduces the impact of outliers $(<5 \%$ of all air quality values of $\hat{x}$ fell outside $\pm 2 \sigma_{x}$ ) and allows for a straightforward comparison between different data sets. Thus, when comparing two variables, $\hat{x}_{1}$ and $\hat{x}_{2}$, a significant association with mean regression slope $\Delta \hat{x}_{2} / \Delta \hat{x}_{1}=1$ implies that a 1 standard deviation (SD) change in variable 2 is associated with a $1 \mathrm{SD}$ change in variable 1 . Comparing different variable associations in this manner allows a direct comparison between variable sensitivities (e.g., $\Delta \hat{x}_{2} / \Delta \hat{x}_{1}$ vs. $\left.\Delta \hat{x}_{3} / \Delta \hat{x}_{1}\right)$. In the current context, $x$ represents the annual or single-season average (or sum as in the case of precipitation) of a variable such as ozone concentration or temperature.

\section{Results}

\subsection{Annual trends in gaseous concentrations compared to emissions of primary species}

\subsubsection{Ozone}

Annual and seasonal averages of $1 \mathrm{~h} \mathrm{O}_{3}$ data obtained from NPS for the period 1999-2013 are plotted in Fig. 3. The trend for the $\mathrm{O}_{3}$ season (April-October) is not shown because it is nearly indistinguishable from that for the third quarter (July-August), labeled "summer". The trends are similar to that observed for $\mathrm{O}_{3}$ using the National Ambient Air Quality Standard (NAAQS) metric - based on the annual fourth highest of the maximum daily $8 \mathrm{~h}$ average (not plotted here) - and indicate only a slightly negative trend for 1999-2011. This change is much more modest (about $0.3 \mathrm{ppbv} \mathrm{yr}^{-1}$ or $<1 \% \mathrm{yr}^{-1}$ ) than the trend in domain emissions of $\mathrm{NO}_{x}$ (an

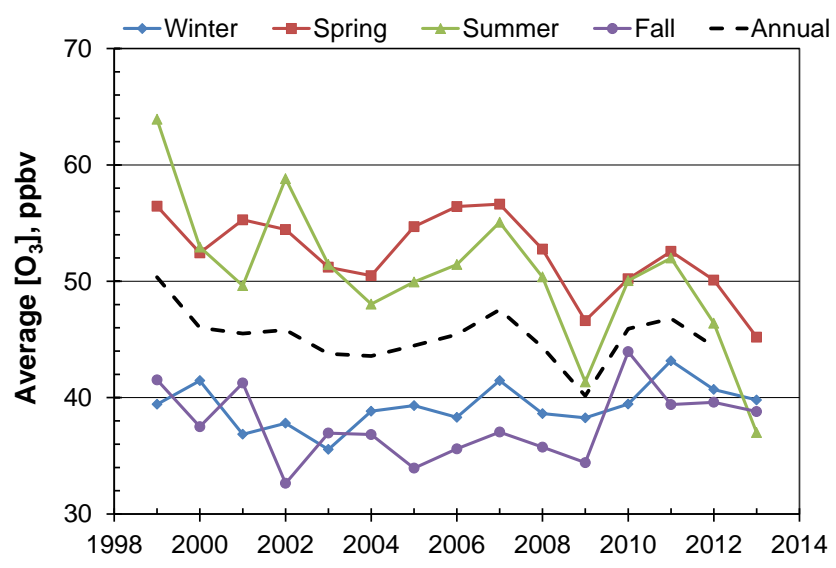

Figure 3. Ozone trends by season and annually at Look Rock, 1999-2013.

$\mathrm{O}_{3}$ precursor) for the 2002-2011 period. The $\mathrm{O}_{3}$ trends for the second $\left(-0.5 \mathrm{ppbv} \mathrm{yr}^{-1} ;-0.9 \% \mathrm{yr}^{-1} ;-0.13 \sigma \mathrm{yr}^{-1}\right)$ and third quarters $\left(-1.0 \mathrm{ppbv} \mathrm{yr}^{-1} ; \quad-1.9 \% \mathrm{yr}^{-1}\right.$; $-0.15 \sigma \mathrm{yr}^{-1}$ ) were significant at $p<0.05$, but this was not true of the annual $\left(-0.3 \mathrm{ppbv} \mathrm{yr}^{-1} /-0.11 \sigma \mathrm{yr}^{-1}\right)$, first-quarter $\left(0.2 \mathrm{ppbv} \mathrm{yr}^{-1} / 0.09 \sigma \mathrm{yr}^{-1}\right)$, and fourth-quarter $\left(0.1 \mathrm{ppbv} \mathrm{yr}^{-1} / 0.03 \sigma \mathrm{yr}^{-1}\right)$ changes. Likewise, the association between quarterly $\mathrm{O}_{3}$ and annual $\mathrm{NO}_{x}$ emissions was positive and highly significant for the spring and summer quarters $\left(0.7<\Delta \hat{x}_{\mathrm{O} 3} / \Delta \hat{x}_{\mathrm{NO} x}<0.8\right)$, when high photochemical reactivity should enable regional emissions to have the greatest impact on ozone observed at Look Rock, but not for the other quarters, when ozone had small, positive changes.

Zero or slightly upward $\mathrm{O}_{3}$ patterns during the first and fourth quarters - when photochemistry is low and contributions from local and regional sources are at a minimum have occurred despite reductions in regional $\mathrm{NO}_{x}$ emissions. These observations may be due in part to reduced emitted $\mathrm{NO}_{x}$ titrating less $\mathrm{O}_{3}$ during the winter and fall periods. If true, this pattern implies the relative importance of longrange (i.e., background) ozone transport during the cooler seasons. Cooper et al. (2014) reviewed global ozone data trends and noted significant increases in ozone across the Pacific Ocean (from Japan to Hawaii and the Pacific coast of western North America) since at least 1990, with annual levels climbing from 30-40 ppbv in the early 1990s to 3545 ppbv by 2010 along the US west coast (changes equal to $0.27 \mathrm{ppbv} \mathrm{yr}^{-1}$ ). Annual average Look Rock data do not indicate similar increases, but some influence from long-range transport cannot be ruled out in light of the $0.2 \mathrm{ppbv} \mathrm{yr}^{-1}$ increases during the winter quarter. Large regional decreases are noted across the eastern US in summer and increases are reported in winter (Cooper et al., 2014) during the first part of the 21st century, in agreement with Look Rock data. However, the Look Rock springtime $\mathrm{O}_{3}$ decrease contrasts with little change elsewhere in the eastern US, but this dis- 
Table 2. Trends in annual concentrations of selected aerosol fine mass and gas species at Look Rock.

\begin{tabular}{|c|c|c|c|c|c|c|c|c|}
\hline Species & $\begin{array}{r}\mathrm{PM}_{2.5} \\
\text { Mass }\end{array}$ & Sulfate & $\mathrm{NH}_{4}^{+\mathrm{a}}$ & $\mathrm{OC}$ & $\mathrm{EC}$ & $\begin{array}{r}\mathrm{SO}_{2}, \\
\mathrm{ppbv}^{\mathrm{b}}\end{array}$ & $\begin{array}{l}\mathrm{NO}_{y}, \\
\text { ppbv }\end{array}$ & $\begin{array}{r}\mathrm{O}_{3}, \\
\text { ppbv }\end{array}$ \\
\hline Annual change, 1999-2013 & $\begin{array}{r}-0.45 \\
\mu \mathrm{g} \mathrm{m}^{-3}\end{array}$ & $\begin{array}{r}-0.23 \\
\mu \mathrm{g} \mathrm{m}^{-3}\end{array}$ & $\begin{array}{l}-0.053 \\
\mu \mathrm{g} \mathrm{m}^{-3}\end{array}$ & $\begin{array}{l}-0.088 \\
\mu \mathrm{g} \mathrm{m}^{-3}\end{array}$ & $\begin{array}{r}-0.019 \\
\mu \mathrm{g} \mathrm{m}^{-3}\end{array}$ & $\begin{array}{r}-0.14 \\
\text { ppbv }\end{array}$ & NA & -0.30 \\
\hline$\%$ change $\mathrm{yr}^{-1}, \mathrm{c} 1999-2013$ & -5.0 & -6.6 & -4.9 & -5.3 & -5.5 & -10.7 & NA & -0.7 \\
\hline Ave. $\sigma_{f}^{\mathrm{d}}$ change $\mathrm{yr}^{-1}, 1999-2013$ & -0.21 & -0.20 & -0.20 & -0.19 & -0.19 & -0.42 & NA & -0.15 \\
\hline$\%$ change $\mathrm{yr}^{-1}, 1988-2013$ & -2.6 & -3.0 & NA & -2.0 & -2.6 & NA & NA & NA \\
\hline$\%$ change $\mathrm{yr}^{-1}, 2007-2013$ & -8.3 & -14.2 & NA & -8.4 & -9.4 & -25.2 & -14.6 & -1.5 \\
\hline
\end{tabular}

${ }^{a}$ Data not available for 2013.

b CASTNET weekly data are shown except for the last row (2007-2013) that is based on continuous pulsed-fluorescence measurements.

c Average annual percent change was computed as the least-squares regression slope for mean annual concentration vs. year (i.e., average concentration

change per year) divided by the average concentration for the entire period.

${ }^{d}$ Mean interannual change expressed as a fractional standard deviation of the yearly concentration.

crepancy may be caused partly by a different definition of "spring" (Cooper et al., 2014, used March-May).

Trends in the $\mathrm{O}_{3}$ regulatory metric (annual 4th highest daily maximum $8 \mathrm{~h}$ average, "4th8h") in the US have been reported by the U.S. EPA (www.epa.gov/airtrends/ozone.html\# oznat). These more extreme values exhibit greater decreases since 1990 than found in annual average values, in part because air management schemes are focused on reducing the highest concentrations. Using over 100 sites in rural areas across the US, the EPA shows changes in the 10th and 90th percentile values of the 4 th $8 \mathrm{~h}$ of -0.3 and $-1.1 \mathrm{ppbv} \mathrm{yr}^{-1}$, respectively. At Look Rock the 4th8h has declined at a comparatively rapid rate of $1.9 \mathrm{ppbv} \mathrm{yr}^{-1}$ since 1999 . Thus, Look Rock data indicate improvements in the worst $\mathrm{O}_{3}$ levels at a faster rate than seen at most rural sites nationally, consistent with Simon et al. (2015).

\subsection{2 $\mathrm{SO}_{2}$}

Annual $\mathrm{SO}_{2}$ concentrations, based on high-sensitivity hourly pulsed fluorescence data measured at Look Rock, are available from 2007 to the present and show about a $25 \% \mathrm{yr}^{-1} \mathrm{de}-$ crease over the period, compared to a mean reduction rate of $11 \% \mathrm{yr}^{-1}$ since 1999 based on CASTNET weekly $\mathrm{SO}_{2}$ data (Table 2). This reflects the large reductions in $\mathrm{SO}_{2}$ emissions in the domain. Compare the relative reduction rate of $\mathrm{SO}_{2}$ with the reduction rate expressed as a fraction of a standard deviation in the concentration (Table 2): $11 \% \mathrm{yr}^{-1}$ is equivalent to an annual decline of $0.42 \sigma \mathrm{yr}^{-1}$ (i.e., almost a half of a standard deviation per year).

Annual averages of $\mathrm{SO}_{2}$ concentrations from 1999 to the present from CASTNET weekly data and continuous hourly pulsed fluorescence data are shown in Fig. 4 along with a comparison with $\mathrm{NEI}$ and EGU emissions of $\mathrm{SO}_{2}$ in the domain (see discussion below). Hourly, continuous data for $\mathrm{SO}_{2}$ averaged on a shorter, monthly basis show much more month-to-month variability (Fig. 5) due to a combination of seasonal changes in emissions, gas-to-particle conversion

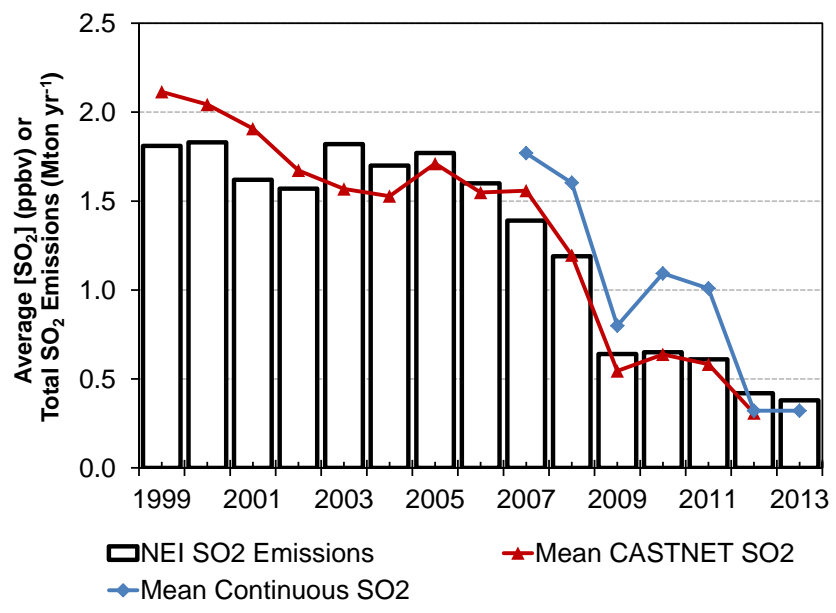

Figure 4. Comparison of annual $\mathrm{SO}_{2}$ concentrations at Look Rock with corresponding total $\mathrm{SO}_{2}$ emissions in the Look Rock domain.

and meteorology-driven scavenging rates. Monthly comparison with hourly $\mathrm{SO}_{2}$ data is less than ideal because CASTNET $\mathrm{SO}_{2}$ data are averaged weekly, but given the similarity in changes, it is reasonable to expect that the conclusions would be the same. The CASTNET data do provide a longer time series for comparison with emissions. A comparison of emissions and CASTNET concentrations (i.e., $\Delta \hat{x}_{\mathrm{SO} 2 \text { (emiss) }}$ vs. $\left.\Delta \hat{x}_{\text {SO2(conc) }}\right)$ for $1999-2013$ produces a highly significant correlation $(p<0.0001)$ with $\Delta \hat{x}_{\mathrm{SO} 2(\mathrm{emiss})} / \Delta \hat{x}_{\mathrm{SO} 2 \text { (conc) }}=$ 0.97 . A similar result was found comparing annually averaged hourly $\mathrm{SO}_{2}$ with $\mathrm{SO}_{2}$ emissions for 2007-2013: $p=$ 0.001 and $\Delta \hat{x}_{\mathrm{SO} 2 \text { (emiss) }} / \Delta \hat{x}_{\mathrm{SO} 2 \text { (conc) }}=1.38$. The sensitivity value $>1$ since 2007 is probably caused by large additional $\mathrm{SO}_{2}$ emission reductions outside the regional domain. Seasonal breakdowns in these comparisons are further enumerated in Table S2 in the Supplement. 


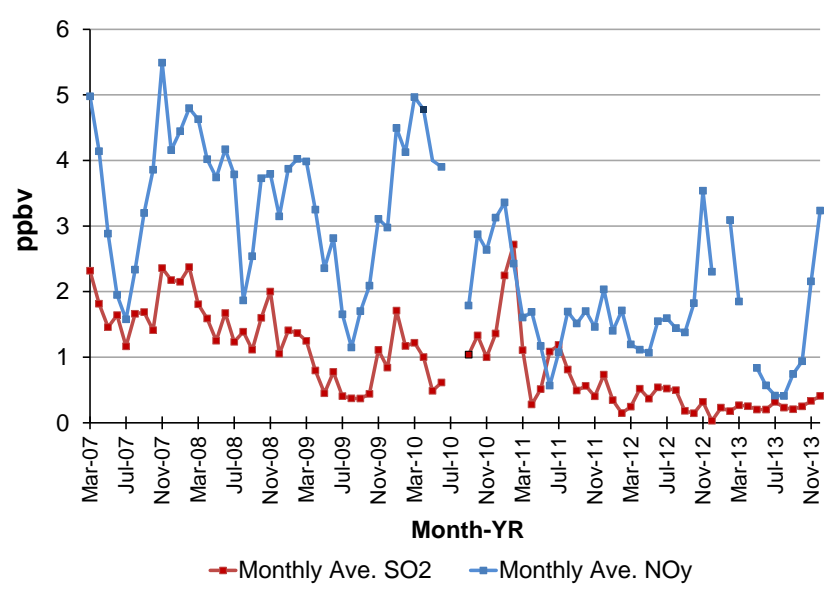

Figure 5. Average monthly $\mathrm{SO}_{2}$ and $\mathrm{NO}_{y}$ concentrations at Look Rock, 2007-2013.

\subsubsection{NO $y$}

Data for NO- $\mathrm{NO}_{x}-\mathrm{NO}_{y}$ concentrations at the site are relatively sparse prior to March 2007 (Fig. 5). Data since 2007 (Table 2) indicate a strong downward trend in $\mathrm{NO}_{y}$ at an average rate of almost $15 \%$ per year. This compares with the negative trend in $\mathrm{SO}_{2}\left(-25 \% \mathrm{yr}^{-1}\right)$ for the same period. The ambient $\mathrm{NO}_{y}$ trend was significantly negative for all four quarters of the year (trend $\approx-0.4 \mathrm{ppbv} \mathrm{yr}^{-1}$ independent of season). This result is similar to that for regional $\mathrm{NO}_{x}$ annual emissions. However, despite similar tendencies, ambient $\mathrm{NO}_{y}$ was not significantly associated with annual $\mathrm{NO}_{x}$ emissions except during the third and fourth quarters. This is likely due to the extreme nonlinearity in $\mathrm{NO}-\mathrm{NO}_{2}-\mathrm{NO}_{z}$ $\left(\mathrm{NO}_{z}=\mathrm{NO}_{y}-\mathrm{NO}_{x}\right)$ chemistry and the spatial inhomogeneity of $\mathrm{NO}_{y}$. It is possible that the significant associations during two quarters were coincidental or represented a serendipitous agreement between regional emission trends and trends for sources directly impacting Look Rock air quality during those periods.

In addition, $\mathrm{O}_{3}$ was not significantly associated with $\mathrm{NO}_{y}$ except during the third (summer) quarter, when a positive association was determined $\left(\Delta \hat{x}_{\mathrm{O} 3} / \Delta \hat{x}_{\mathrm{NO} y}=0.76\right)$. Again, this may be because Look Rock $\mathrm{NO}_{y}$ data do not reflect regional $\mathrm{NO}_{x}$ emissions. Look Rock ozone appears to only respond significantly (in a positive sense) to local $\mathrm{NO}_{y}$ levels during the summer quarter when weak transport conditions and high photochemical rates coincide. In that quarter, $\mathrm{NO}_{y}$ was significantly linked to only two variables: wind speed (positive sense) and cloud cover (negative sense). This also supports the finding of positive trends observed in ozone for the first and fourth quarters despite the fact that regional $\mathrm{NO}_{x}$ emissions were in strong decline. The conclusion from these results is that local conditions at Look Rock that are influenced strongly by atmospheric photochemical processes (especially ozone and secondary organic aerosol formation) are only characterized by Look Rock measurements during the summer quarter. Data from other times of the year indicate a blend of impacts from local and more distant emissions, consistent with the stronger atmospheric transport and/or slower photochemical processing typical for those seasons.

\subsection{Annual trends in aerosol mass and composition}

All aerosol species for which data are available exhibited an average 2007-2013 negative trend of between 8 and $15 \%$ per year. Only ozone - which has had a modest upward trend in winter and fall quarters - experienced a very small negative annual trend coinciding with the strong negative trends for the other species.

Data used to evaluate trends in aerosol mass and composition at Look Rock include mass and composition data from the IMPROVE network. The IMPROVE database contains every-third-day filter samples (twice weekly prior to 1999). These were examined for the time period 1999 to the present for all trend analyses, and retrospectively back to 1988 for mass, sulfate, ammonium (from 1998 only), OC, and EC levels. The annual averages are shown in Fig. 6 and show smoothly decreasing trends with an accelerated decrease in the 2007 to 2009 period for sulfate that clearly influenced trends in $\mathrm{PM}_{2.5}$ mass. Annual percent reductions in concentrations based on IMPROVE data are shown in Table 2 and

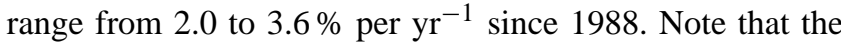
levels of OC as measured by the IMPROVE method actually increased at Look Rock from 1988 to 1998 then decreased from 1998 to the present at a net rate of $2.7 \% \mathrm{yr}^{-1}$.

Comparing Look Rock $\mathrm{PM}_{2.5}$ trends with those from other locations is more complicated than for $\mathrm{O}_{3}$ because aerosols impacting a given site often come from a different mix of pollution source types and pollutant precursor species. Across the eastern US the predominant source of $\mathrm{PM}_{2.5}$ has been sulfate from $\mathrm{SO}_{2}$ emitted by fossil fuel combustion. However, some locations are more influenced than others by biomass burning, biogenic organic aerosols, windblown dust, and so forth (see, for example, Chalbot et al., 2013, whose $\mathrm{PM}_{2.5}$ source analysis included many of the same regions that impact Look Rock). Trends in these different source types influence overall trends in $\mathrm{PM}_{2.5}$ pollution. The EPA tracks trends in annual average $\mathrm{PM}_{2.5}$ concentrations at both the national and regional level (www.epa.gov/airtrends/pm.html\#pmreg). Data from 2000 to 2013 indicate national trends in 10th and 90th percentile levels of $\mathrm{PM}_{2.5}$ pollution of -0.19 and $-0.51 \mu \mathrm{g} \mathrm{m}^{-3} \mathrm{yr}^{-1}$, respectively. At Look Rock the trend for this same period was $-0.46 \mu \mathrm{g} \mathrm{m}^{-3} \mathrm{yr}^{-1}$, or near the upper end of the nationally observed trends. Regionally, the Look Rock trend compares with those from nearby regions (all units in $\mu \mathrm{g} \mathrm{m}^{-3} \mathrm{yr}^{-1}$ ): -0.46 (Ohio River valley, which includes Tennessee/Look Rock in EPA's regional definition), -0.42 (northeastern US), -0.41 (southeastern US, which includes states immediately south and east of Look Rock), and -0.24 (south-central US, including Texas). Thus, the Look 


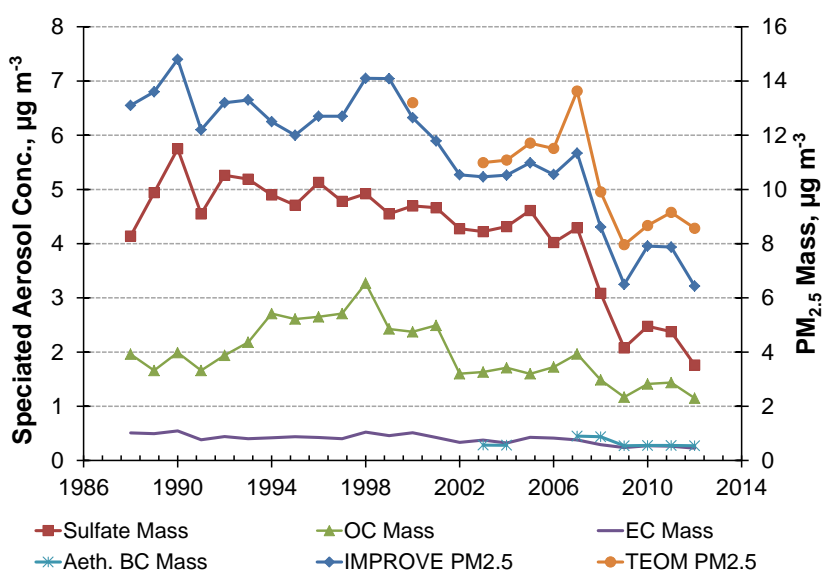

Figure 6. Trends in annual average IMPROVE $\mathrm{PM}_{2.5}$ mass, sulfate, $\mathrm{NH}_{4}^{+}, \mathrm{OC}, \mathrm{EC}$, and BC at Look Rock.

Rock $\mathrm{PM}_{2.5}$ trend is most similar to that for the Ohio River valley region, which is a major source region for $\mathrm{SO}_{2}$.

Since 1999 the decreases in aerosol mass and its major constituents are all in a narrow range from 3.1 to $4.2 \% \mathrm{yr}^{-1}$ despite significant interannual variability. From comparison of the results reported in Table 2 for sulfate with trends reported by Hand et al. (2012), it can be seen that there is excellent agreement in trends $\left(-4.2 \% \mathrm{yr}^{-1}\right.$ for Look Rock compared to $-3.1 \% \mathrm{yr}^{-1}$ for six southeastern long-term (19922010) IMPROVE sites) and $-4.4 \% \mathrm{yr}^{-1}$ for 13 short-term southeastern sites (2001-2010). This suggests that the trends observed at Look Rock are typical of the non-urban southeast and that the observed decreases in $\mathrm{PM}_{2.5}$ mass levels are due to decreases in both sulfate and organic carbon. Ammonium levels are expected to decrease with sulfate assuming the extent of neutralization of aerosol sulfate does not change. However, ammonium was not measured at the site in a long-term context. Levels of other aerosol constituents not shown in Fig. 6 (e.g., metal oxides) may also have decreased during the period, but, with the possible exception of nitrate during winter months, these constituents contribute at most a few percent of the $\mathrm{PM}_{2.5}$ mass. For example, in 2001, nitrate as $\mathrm{NH}_{4} \mathrm{NO}_{3}$ in FRM filter measurements made at Look Rock averaged $12.9 \%$ of $\mathrm{PM}_{2.5}$ mass in winter but $<1 \%$ averaged over the remaining seasons (Tanner et al., 2004b). More recently, Budisulistiorini et al. (2015) reported that, in 2013, $\mathrm{NH}_{4} \mathrm{NO}_{3}$ varied between 4 (summer) and 9 (winter) percent of total $\mathrm{PM}_{1}$ mass (" $\mathrm{PM}_{1}$ " denotes aerosols with aerodynamic diameters $<1 \mu \mathrm{m}$ ) mass.

Comparisons of aerosol components against emissions revealed that sulfate, OC, and EC (and by extrapolation, $\mathrm{PM}_{2.5}$ ) were significantly associated with one or both emission species for at least the spring and summer quarters. Details are provided in Table $\mathrm{S} 2$ in the Supplement. The strong covariance between $\mathrm{SO}_{2}$ and $\mathrm{NO}_{x}$ emissions produces cross-correlations with any aerosol component that is signif- icantly associated with at least one of the emission species. However, sulfate was more closely associated (higher $r^{2}$ and lower $p$ values; $p<0.001$ ) with $\mathrm{SO}_{2}$ emissions for each quarter of the year $\left(0.60<\Delta \hat{x}_{\text {sulf }} / \Delta \hat{x}_{\mathrm{NO} x}<0.76\right.$ and $\left.0.76<\Delta \hat{x}_{\text {sulf }} / \Delta \hat{x}_{\mathrm{SO} 2}<1.0\right)$. Conversely, OC was strongly associated with $\mathrm{NO}_{x}$ emissions during the spring $(p<0.01)$ and summer $(p<0.001)$ quarters and OC was associated to a lesser degree with spring, summer, and fall $\mathrm{SO}_{2}$ emissions $\left(0.66<\Delta \hat{x}_{\mathrm{OC}} / \Delta \hat{x}_{\mathrm{NO} x}<0.76\right.$ and $\left.0.44<\Delta \hat{x}_{\mathrm{OC}} / \Delta \hat{x}_{\mathrm{SO} 2}<0.65\right)$. One relationship that stands out is between OC and ambient $\mathrm{NO}_{y(\mathrm{~g})}$. Similar to what was reported in the previous section regarding ozone, OC was significantly associated with $\mathrm{NO}_{y(\mathrm{~g})}$ only during the third quarter $\left(\Delta \hat{x}_{\mathrm{OC}} / \Delta \hat{x}_{\mathrm{NO} y}=0.86\right)$, perhaps reflecting a unique combination of factors occurring only during summer. Finally, EC was more closely linked with $\mathrm{SO}_{2}$ emissions than $\mathrm{NO}_{x}$ emissions for each quarter $\left(p \leq 0.001\right.$ for $\mathrm{SO}_{2}$ in all seasons), although the $\mathrm{SO}_{2 \text { (emiss) }}: \mathrm{NO}_{x}$ (emiss) covariance muddles interpretation of the data.

Another notable change in aerosol composition is reflected in the relative abundances among the primary species measured at Look Rock. The change in relative abundances of the major fine particle types is best seen by examining the IMPROVE data from 1999 and 2013 (Fig. 7). The ammonium sulfate component is much smaller in 2013, as already described. Ammonium nitrate remained a very small component but did increase somewhat in response to the greater availability of ammonium. The relative abundances of organic aerosol and EC mass remained about the same despite decreases in concentrations. Even the "unknown" component - believed to be associated with an unattributed organic contribution or water - decreased by just over $50 \%$ (nearly the same amount as the organic component). It is important to note that the IMPROVE estimated organic mass is determined by applying a fixed adjustment factor of 1.8 to measured OC concentrations to account for the other elements associated with the unidentified organic compounds (Malm et al., 2011).

\subsection{Relationship to long-term trends in meteorology}

It is reasonable to consider whether these trends in aerosol and trace gas levels are associated with meteorological trends at Look Rock. Data from the NWS at the nearby Knoxville airport in Maryville and from Look Rock indicate similar patterns since 1999. There is no evidence of either annual or seasonal precipitation or temperature trends, nor are these meteorological variables correlated with measured air quality changes (details on the long-term trends in temperature and precipitation and the year-to-year variability in those trends at Look Rock are given in the Supplement). Likewise, no significant 15-year trends in wind direction frequency, cloud cover, or solar radiation have been detected. A slight upward trend in solar radiation since 2007 was found which would 
1999

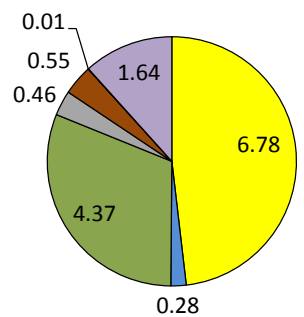

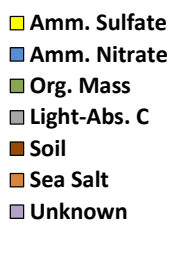

2013

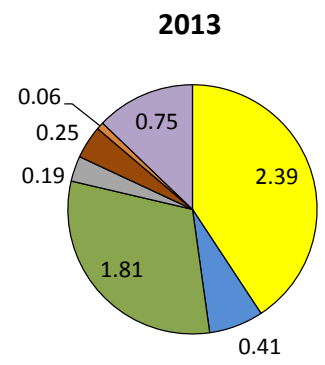

Figure 7. Comparison of IMPROVE PM 2.5 mass chemical distributions for 1999 and 2013 at Look Rock. "Light-Abs. C" denotes the EC component, "Soil" denotes particles of various oxides (e.g., iron oxide) associated with soils and "Unknown" represents mass whose composition is indeterminate (most likely some water along with mass associated with OC that is not included in the 1.8 adjustment factor applied by IMPROVE to OC to estimate OM). Numbers associated with each pie section denotes the annual mean mass $\left(\mu \mathrm{g} \mathrm{m}^{-3}\right.$ ) of that chemical constituent.

suggest an increase in photochemistry, but the net effect on secondary aerosol production is unclear.

A small decline (not statistically significant) since 1999 in the number of high moisture hours (i.e., those with relative humidity $>90 \%$ ) was observed during all seasons but fall. Considering that the interannual variations in this parameter were large, the effect on observed aerosol trends (such as through reduced heterogeneous chemistry) is likely to be small. The only statistically significant, incontrovertible meteorological trend is that of wind speed, which has declined steadily since 1999 at Look Rock. This is consistent with wind speed measurements elsewhere in the US (Pryor et al., 2009; Milton, 2010; Pryor and Ledolter, 2010). The source of this decline is unknown but could be linked to climate change (Pryor et al., 2009) or to physical changes surrounding measurement sites. There is no evidence, however, that physical characteristics have changed significantly in the Look Rock vicinity. A decline in wind speed would reduce distances traveled by pollutants before arriving at Look Rock. This could increase both primary pollutant concentrations - due to a decrease in atmospheric dilution - and secondary pollutants by providing more time for atmospheric conversion. It would also mean an increase in the relative contribution of local emissions to Look Rock compared to more distant sources. In any case, declining wind speeds are not likely the reason behind the observed decreases in pollutant concentrations at Look Rock unless a very nonlinear process is involved.

Some meteorological factors, when viewed on a quarterly basis, were found to be significantly associated with measured air quality values, although they were not contributory to long-term trends. Table 3 summarizes the notable linkages between air quality and meteorology at Look Rock (in all cases $p<0.05$ ). Details of these associations are described in the Supplement to allow comparisons of relative sensitivities
Table 3. Quarters of the year when measured Look Rock air quality was significantly $(p<0.05)$ associated with observed meteorology.

\begin{tabular}{lrrrr}
\hline $\begin{array}{l}\text { Meteorological } \\
\text { parameter }\end{array}$ & Ozone & Sulfate & OC & EC \\
\hline Temperature $^{\mathrm{a}}$ & 3 & - & 3 & - \\
Precipitation $^{\mathrm{b}}$ & 3 & - & 3,4 & 1,4 \\
Wind speed $^{\mathrm{a}}$ & 2,3 & $1,2,3$ & $2,3,4$ & 1,3 \\
Cloud cover $^{\mathrm{b}}$ & 3 & - & 3,4 & - \\
Solar radiation $^{\mathrm{c}}$ & 4 & 2 & 4 & - \\
High RH $^{\mathrm{b}}$ & 4 & - & 4 & 2 \\
\hline
\end{tabular}

a Positive association.

b Negative association.

c Positive for ozone and OC, negative for sulfate.

across different species and meteorological factors. The quarter of the year when a significant association was identified is noted in the table for each combination of air quality and meteorological factor. The summer (third) and fall (fourth) quarters had the most significant linkages. Wind speed was most frequently associated with air quality (positively in all cases). Thus, speed is not an indicator of dilution but rather something else, perhaps an increasing linkage between Look Rock air quality and local emissions with an increasing role for "Look Rock domain" emissions as speed declines. Ozone, $\mathrm{OC}$, and EC are occasionally negatively associated with precipitation, which acts as a scavenger of pollutants. Ozone and OC are both positively linked with temperature during summer with higher temperatures associated with more biogenic precursor emissions (Lamb et al., 1993) and faster photochemical reactions (e.g., Alley and Ripperton, 1962; Seinfeld and Pandis, 1998). Cloud cover and solar radiation are generally anticorrelated. Insolation (reduced by cloud cover) is a driver for photochemistry, although neither it nor clouds appear as significant drivers during all quarters. Insolation was negatively associated with sulfate during the spring quarter for reasons that are not apparent. What is also unexpected is the negative association between ozone/OC/EC and high relative humidity conditions (i.e., frequency of humidity levels $>90 \%$ ) at Look Rock. Typically, clouds impact the monitoring site directly (i.e., place the site in fog) under such humid conditions. The occasional negative association between some air quality levels (i.e., ozone and OC) on the one hand and cloud cover and high humidity on the other might represent the same effect on photochemistry, but the physical basis for an impact on EC is not obvious.

\subsection{Seasonal trends in concentrations of primary and secondary aerosol species}

Although located in the southeast US, the Look Rock site experiences four distinct seasons and seasonal differences in meteorology and atmospheric chemistry can significantly affect trends in concentrations and the degree to which changes 

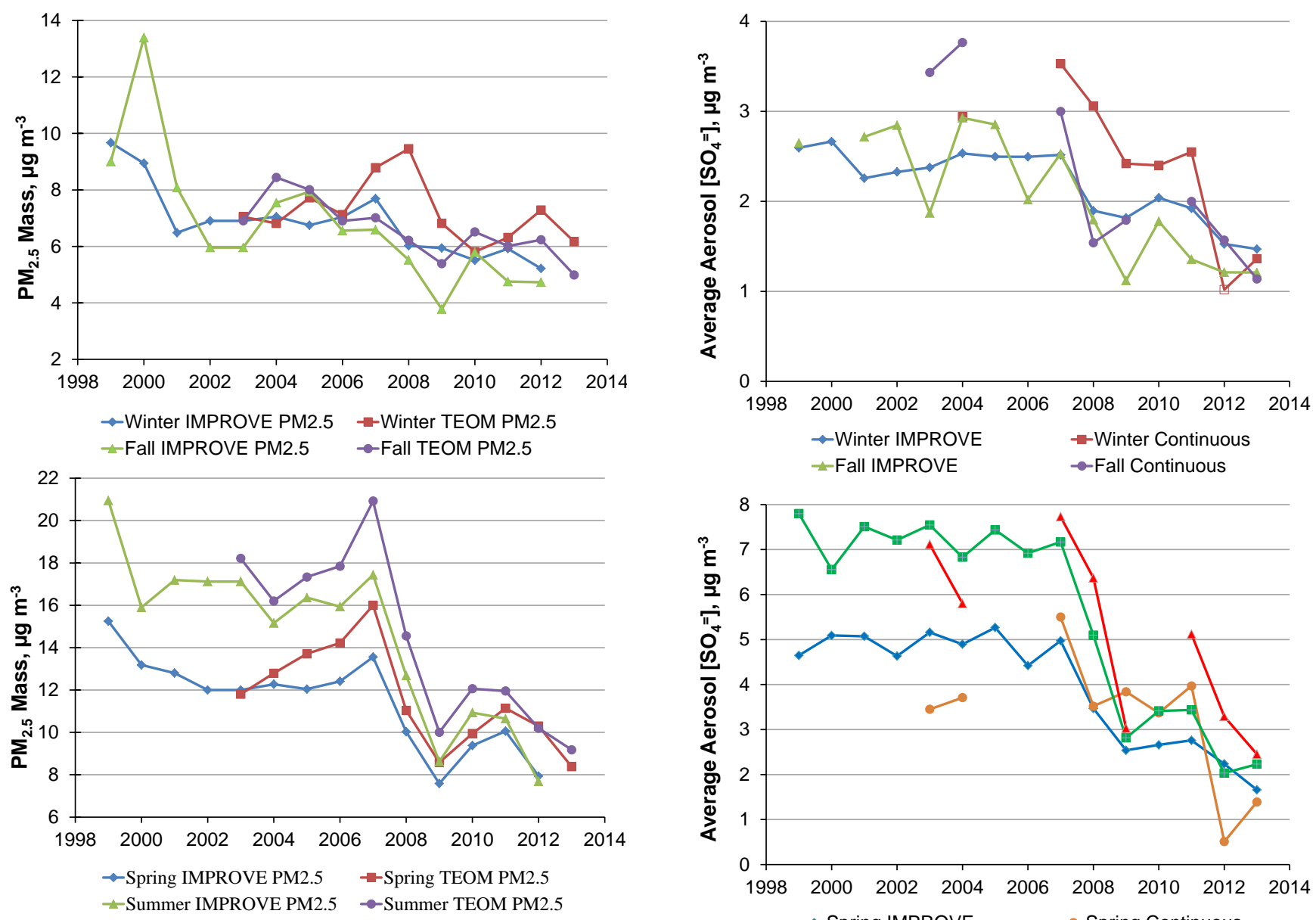

Figure 8. Trends in seasonal $\mathrm{PM}_{2.5}$ mass at Look Rock.

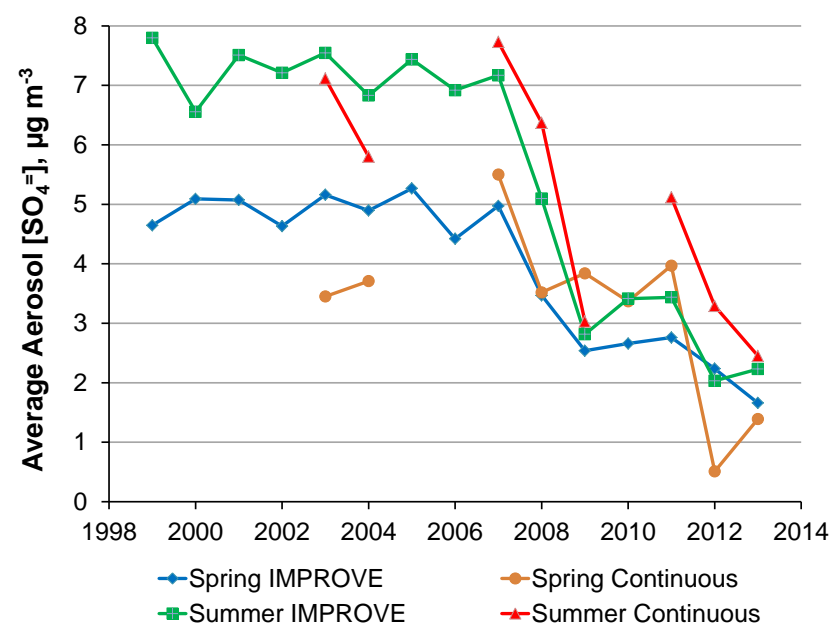

Figure 9. Trends in seasonal $\mathrm{PM}_{2.5}$ sulfate mass at Look Rock.

in primary emissions are reflected in measured air quality. Fine mass by either filter or continuous TEOM methods trends down for all seasons (Fig. 8), but the trend is dramatically sharper for the spring and summer data, especially for the 2007-2009 period. This sharp decline is probably due to a combination of meteorology and emission reductions: 2009 was a wetter, cooler year than 2007, with 2008 being intermediate between the two, which would reduce the amount of photochemical processing and secondary aerosol formation. The period 2007-2009 also saw the largest reductions in EGU emissions of both $\mathrm{SO}_{2}$ and $\mathrm{NO}_{x}$ within the domain. As a result, annual averages of TEOM-based PM $_{2.5}$ mass, hourly sulfate, and IMPROVE OC decreased by 42,52 , and $40 \%$, respectively, from 2007 to 2009 compared to 54 and $63 \%$ reductions in total $\mathrm{SO}_{2}$ and $\mathrm{NO}_{x}$ emissions (respectively) in the domain.

Consistent with these observations, observed sulfate levels at Look Rock declined more sharply in spring and summer compared to fall and winter (Fig. 9), and again declines were most pronounced in the 2007-2009 period. However, the trend in summer season sulfate was more sharply downward than in the spring season, and since about 2009 there have

been no significant differences between average spring and summer values. Along with seasonal changes in emissions, differences in meteorological parameters between spring and summer seasons - specifically average wind speeds and precipitation totals (both lower in summer) - may have contributed to accumulation of higher sulfate levels in summer vis-à-vis spring in the period before these sharp decreases in $\mathrm{SO}_{2}$ emissions occurred. However, it is unclear what this observation implies about the relative importance of gas-phase and aqueous-phase $\mathrm{SO}_{2}$-to-sulfate conversion mechanisms and the relative pathways for $\mathrm{SO}_{2}$ removal (reaction vs. deposition) in the region in the future.

Figure 10 shows the IMPROVE data for OC, parsed by season for the 1999-2012 period. With the exception of some anomalously high values of unknown origin in the fall seasons of 2000 and especially 2001, the trend in OC values is generally down (about $30 \%$ decrease in 2012 compared to 1999 ) but not as much as for fine mass and sulfate (55 and $58 \%$, respectively). There are two important caveats: comparing Fig. 10 with the longer term OC record in Fig. 6 reveals that there was an upward trend in measured OC from 


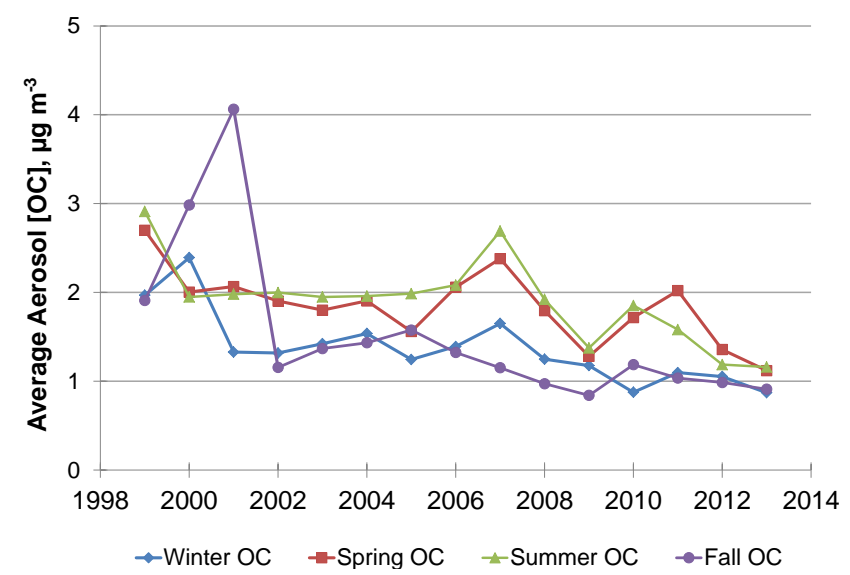

Figure 10. Trends in seasonal IMPROVE $\mathrm{PM}_{2.5}$ OC mass at Look Rock.

the late 1980s to the late 1990 s prior to the decrease observed in the last 10-15 years. Second, the seasonal decrease in OC since 1999 is similar for all four seasons. This suggests that $\mathrm{PM}_{2.5}$ reductions at the site derive from reductions in both carbonaceous and sulfate aerosol levels which have differing seasonal patterns, likely because of different seasonal patterns in their respective emission sources. The different seasonal behaviors of OC and sulfate in response to meteorological factors - as illustrated by the data in Table 3 - may also come into play. This is supported by seasonal trends data for $\mathrm{EC}$ and $\mathrm{BC}$ illustrated in Fig. 11.

\section{Sources of aerosol organic matter (OM)}

A continuing source of uncertainty regarding the origin of secondary organic matter in atmospheric aerosols relates to the fraction of particle organic matter (OM) derived from anthropogenic activities vs. that which originates from natural processes (Weber et al., 2007; Hoyle et al., 2011; Shilling et al., 2013). The most effective tool used to date to refine estimates of that fraction is measurement of the ${ }^{14} \mathrm{C}$ content of aerosol samples from which the fractions of "modern" $\left(f_{\mathrm{m}}\right)$ and fossil carbon can be determined because ${ }^{14} \mathrm{C}$ in fossil sources of carbon has decayed to zero (Stuiver and Polach, 1977). With respect to control strategies for atmospheric aerosol carbon in PM, this estimation is complicated by the fact that anthropogenic activities such as agricultural burning and prescribed forest burns contribute modern aerosol carbon as do vegetative emissions. An additional complication is the unexpected correlation of $f_{\mathrm{m}}$ with certain anthropogenic compounds (e.g., CO). Biomass burning samples present a challenge in interpretation of ${ }^{14} \mathrm{C}$ content due to the varying age of carbonaceous material in biomass fuel and due to the fact that atmospheric ${ }^{14} \mathrm{C}$ content is decaying to its cosmic ray background from higher levels caused by nuclear bomb tests in the 20th century. One approach to re-
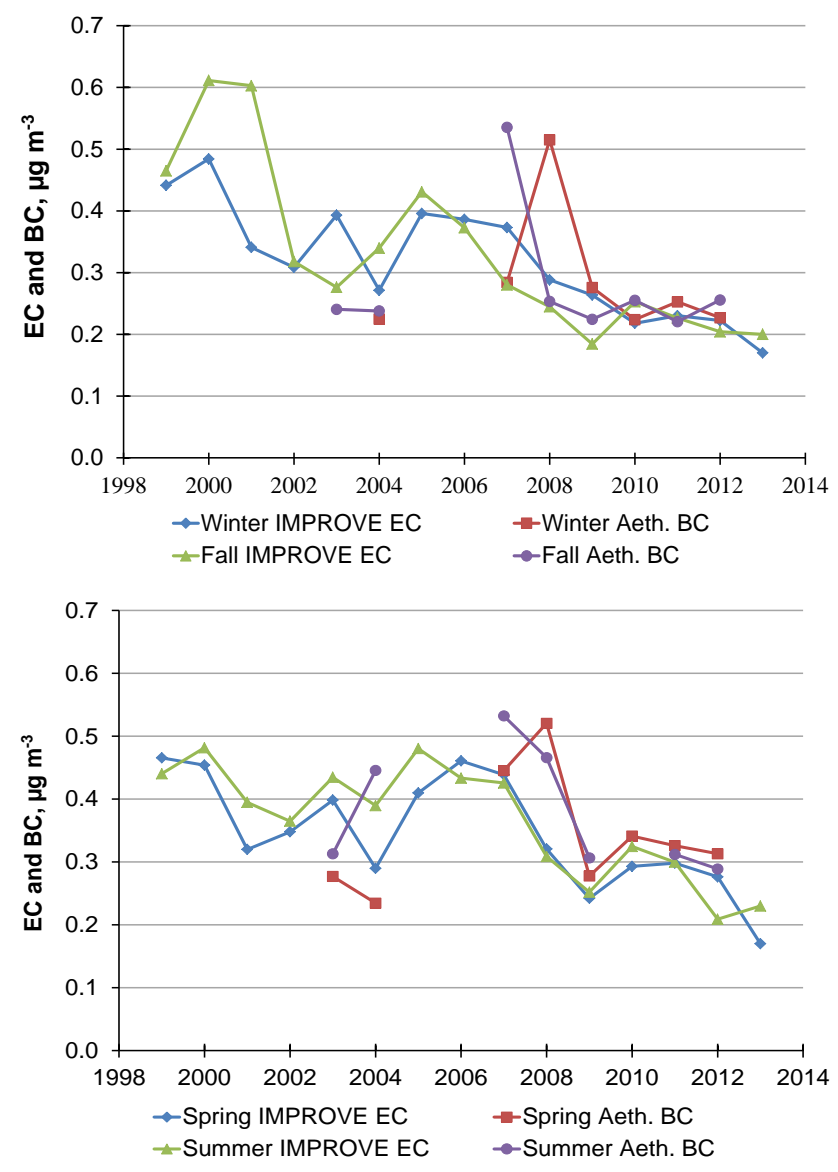

Figure 11. Trends in seasonal $\mathrm{PM}_{2.5} \mathrm{EC}$ and $\mathrm{BC}$ mass at Look Rock.

solving this problem (not used herein) would involve using different correction factors for modern aerosol carbon from biomass burning (carbon of varying age) and for aerosol carbon from current biogenic emissions as has been recently reported by Zotter et al. (2014).

Measurements of the fraction of modern carbon, $f_{\mathrm{m}}$, have been made at Look Rock and other sites in the southeast US using $24 \mathrm{~h}$ filter-based $\mathrm{PM}_{2.5}$ high-volume samples (Tanner et al., 2004a; Bench et al., 2007). These indicate that $f_{\mathrm{m}}$ is consistently high (60-90\%) for rural locations in all seasons (see Table 4). As shown in Fig. 6, OC concentrations have decreased (at least since 1998) at the Look Rock site at a rate comparable to that of inorganic constituents of $\mathrm{PM}_{2.5}$, and there is no evidence to date that $f_{\mathrm{m}}$ in $\mathrm{OM}$ at southeastern US sites such as Look Rock changed, as the overall $\mathrm{PM}_{2.5}$ levels have dropped by $49 \%$ from 1988 to 2005 (see $f_{\mathrm{m}}$ data in Tanner and Gaffney, 1986). Since OM is now often the most abundant contributor to $\mathrm{PM}_{2.5}$, it is important to parse out which sources have the most contribution to $\mathrm{PM}_{2.5}$ and OM mass. Until recently there were no reliable techniques which separately identify the $f_{\mathrm{m}}$ of elemental and organic carbon in the same sample. This has hampered the use of 
Table 4. Summary of ${ }^{14} \mathrm{C}$ data for aerosol carbon in $\mathrm{PM}_{2.5}$ samples from Look Rock and other non-urban southeastern US sites, $2002-2005$.

\begin{tabular}{llrrr}
\hline $\begin{array}{l}\text { Sampling } \\
\text { location }\end{array}$ & $\begin{array}{l}\text { Sample season } \\
\text { and duration }\end{array}$ & $\begin{array}{r}\text { Average [OC], } \\
\mu \mathrm{g} \mathrm{m}^{-3}\end{array}$ & $\begin{array}{r}\text { Average } f_{\mathrm{M}}^{\mathrm{a}} \text {, } \\
(\mathrm{SD})\end{array}$ & $\begin{array}{r}\text { No. of } \\
\text { Samples }\end{array}$ \\
\hline Look Rock, GSMNP & 24h, summer, 2002 & 3.3 & $0.834(0.082)$ & 14 \\
Muscle Shoals, AL & 24 h, winter, 2003 & 2.7 & $0.787(0.085)$ & 12 \\
Look Rock, GSMNP & 24h, spring, 2004 & 3.6 & $0.774(0.091)$ & 9 \\
Look Rock, GSMNP & 6-day, summer, 2004b & 2.72 & $0.972(0.082)$ & 13 \\
Look Rock, GSMNP & 24h, summer, 2004 & 3.2 & $0.712(0.080)$ & 11 \\
Look Rock, GSMNP & 24h, fall, 2004 & 3.1 & $0.692(0.108)$ & 11 \\
Look Rock, GSMNP & 6-day, winter, 2005 & 1.28 & $0.885(0.057)$ & 13 \\
Look Rock, GSMNP & 24h, winter-spring, 2005 & 2.8 & $0.746(0.140)$ & 12 \\
Mammoth Cave NP & 24h, spring, 2004 & NA & $0.784(0.078)$ & 10 \\
Mammoth Cave NP & 24h, summer, 2004 & NA & $0.749(0.146)$ & 12 \\
Mammoth Cave NP & 24h, fall, 2004 & NA & $0.670(0.080)$ & 12 \\
Mammoth Cave NP & 24h, winter-spring, 2005 & NA & $0.656(0.096)$ & 13 \\
Shenandoah NP & 24h, spring, 2004 & NA & $0.759(0.124)$ & 11 \\
Shenandoah NP & 24h, summer, 2004 & NA & $0.741(0.162)$ & 12 \\
Shenandoah NP & 24h, fall, 2004 & NA & $0.610(0.130)$ & 12 \\
Shenandoah NP & 24h, winter-spring, 2005 & NA & $0.592(0.111)$ & 10 \\
\hline
\end{tabular}

${ }^{\mathrm{a}}$ Corrected fraction of modern carbon.

${ }^{\text {b }}$ Samples collected by IMPROVE staff and analyzed by Lawrence Livermore National Laboratory (LLNL) (Bench et al., 2007).

aerosol mass spectrometry results to identify and quantify contributions to OM from biomass burning, along with secondary organic aerosol derived from biogenic emissions of isoprene and terpenes. Recent advances reported by Zhang et al. (2012) and Zotter et al. (2014) may improve our ability to do so using composited samples taken during the 2013 SOAS experiments.

\section{Atmospheric transport and aerosol trends}

Trends in $\mathrm{PM}_{2.5}$ were examined within trajectory coordinate clusters (Sect. 2.3) to determine which transport scenarios contributed most to the observed overall negative $\mathrm{PM}_{2.5}$ trends previously described (Table 5). Cluster populations and the fraction of total variance (in transformed cluster coordinates) decrease as cluster number increases. Also, the lower cluster numbers usually included data from the largest range in years and, thus, most often provided statistically significant (with a minimum 95 percent confidence) trends in $\mathrm{PM}_{2.5}$. Locations of the top 10 clusters (based on clusteraveraged $12 \mathrm{~h}$ upwind trajectory locations) are illustrated in Fig. 12. Numbered ellipses contain the 100 and $500 \mathrm{~m}$ trajectory centroids for each cluster. Shaded clusters are those associated with significant downward trends in $\mathrm{PM}_{2.5}$ concentrations. Symbols denoting the locations of Look Rock and Knoxville are plotted for spatial reference. Table 5 lists the $\mathrm{PM}_{2.5}$ changes over time for the top eight 12 and $24 \mathrm{~h}$ trajectory clusters (parts a and $b$, respectively). These clusters accounted for $>60 \%$ of the total variance in cluster location for each upwind period and more than half the total number of trajectories analyzed. Although some clusters experienced

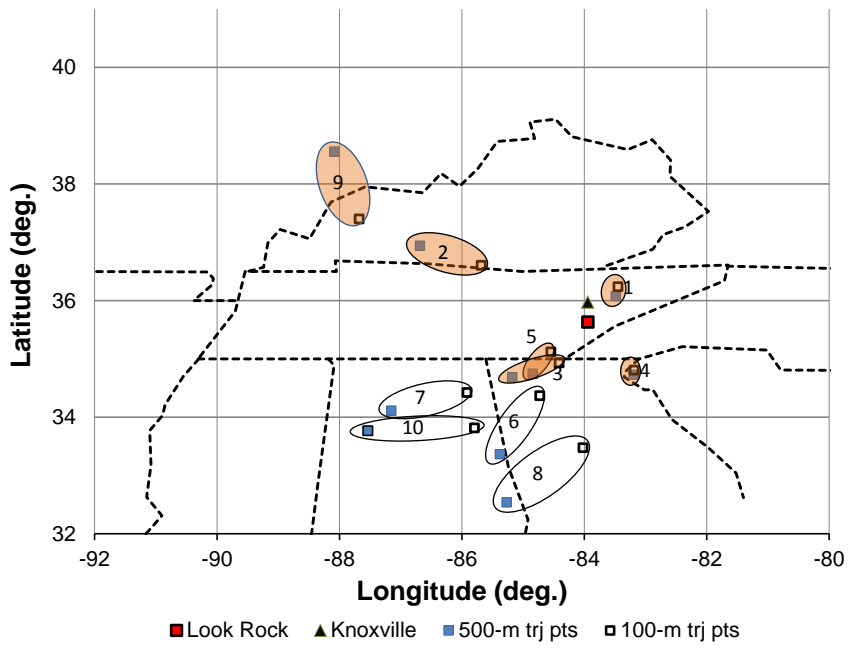

Figure 12. Locations of cluster centroids (numbered ellipses) for computed 100 and $500 \mathrm{~m}$ air trajectories at $12 \mathrm{~h}$ upwind (pairs of squares within ellipses) from Look Rock (red square) for selected extreme $\mathrm{PM}_{2.5}$ episodes during 2007-2013. Shaded ellipses denote clusters for which significant negative $\mathrm{PM}_{2.5}$ mass trends at Look Rock were identified.

increased $\mathrm{PM}_{2.5}$ over time, the weighted trend remains negative when higher-order/lower-numbered clusters are added together (see last column in each part of the table). The $\mathrm{PM}_{2.5}$ trend across all trajectories (there is no difference in trajectory age because all are associated with the same $\mathrm{PM}_{2.5}$ data) was $-1.35 \mu \mathrm{g} \mathrm{m}^{-3} \mathrm{yr}^{-1}$, which is significant at the $99 \%$ confidence level. 


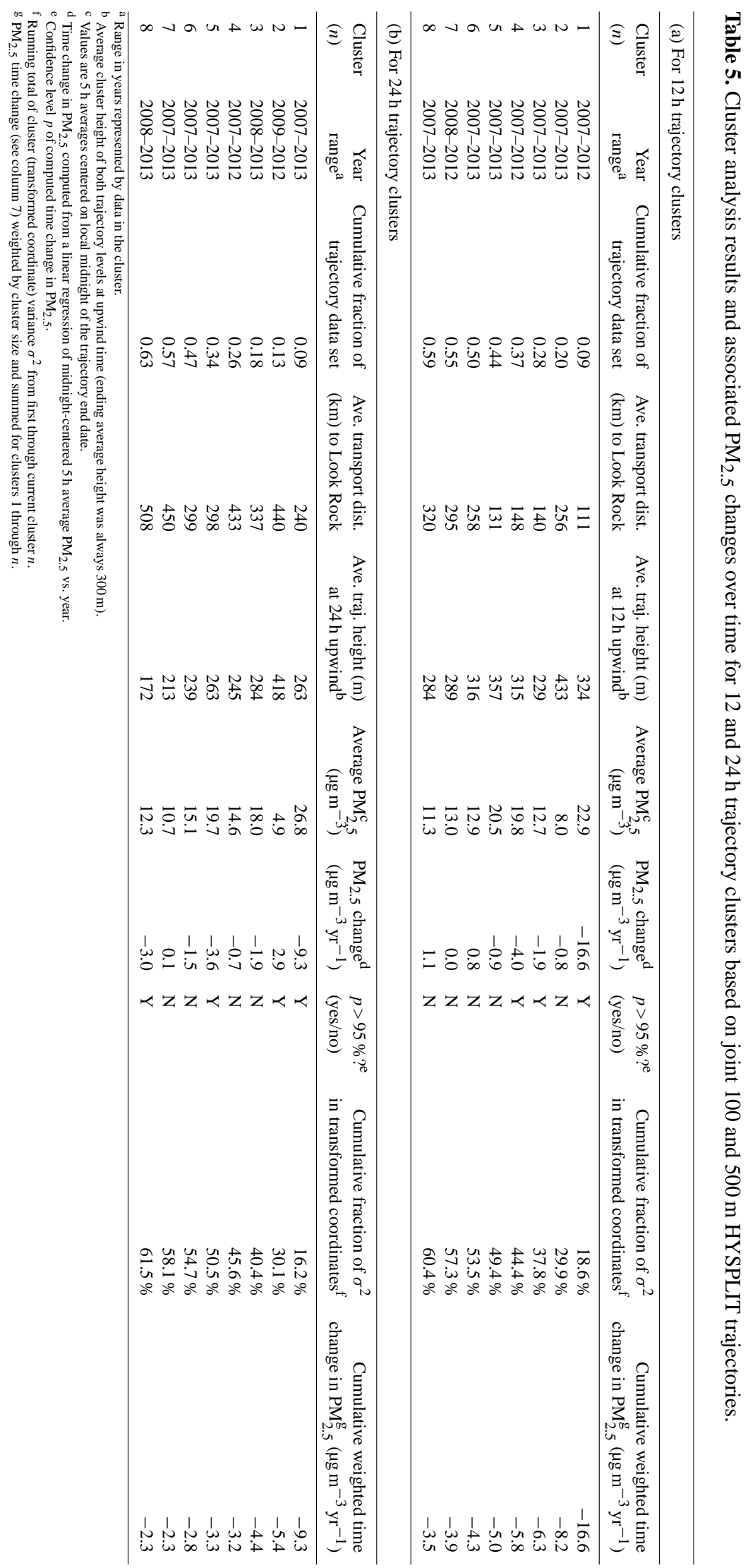




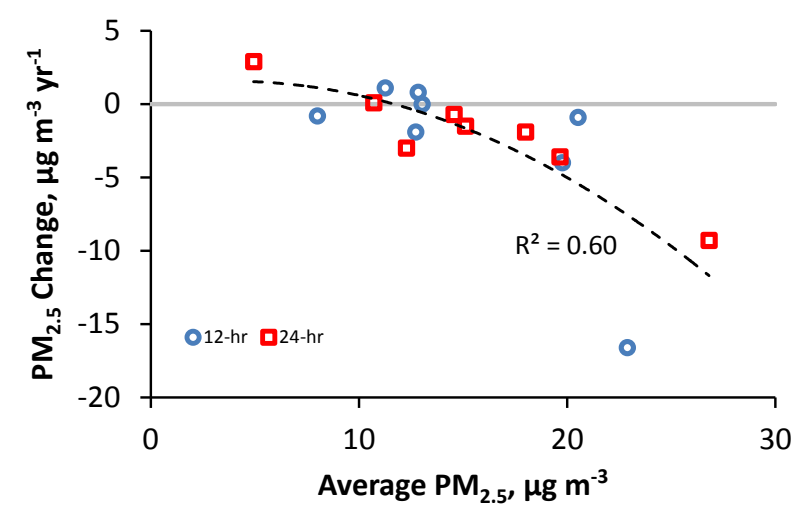

Figure 13. Weighted trend of $\mathrm{PM}_{2.5}$ mass by 12 and $24 \mathrm{~h}$ trajectory clusters.

A plot of $\mathrm{PM}_{2.5}$ changes over time vs. cluster-averaged $\mathrm{PM}_{2.5}$ (Fig. 13) indicates that the rate of change becomes increasingly negative as $\mathrm{PM}_{2.5}$ exceeds $12 \mu \mathrm{g} \mathrm{m}^{-3}$. The rate of change is slightly positive when $\mathrm{PM}_{2.5}<12 \mu \mathrm{g} \mathrm{m}^{-3}$. The trajectory age (i.e., 12 or $24 \mathrm{~h}$ upwind) makes no difference. The downward trend in $\mathrm{PM}_{2.5}$ mass is caused principally by reductions in aerosol mass when conditions are such that aerosol levels are high (i.e., there is no evidence of a downward trend when aerosol levels are low), and that may be caused by a combination of meteorological factors and emission changes. As shown in Table 5, cluster 1 for both 12 and $24 \mathrm{~h}$ upwind had the highest average $\mathrm{PM}_{2.5}$ and the largest decreases in $\mathrm{PM}_{2.5}$ over 2007-2013. Note that the 12 and $24 \mathrm{~h}$ (upwind) trajectory clusters were not the same because of differences in upwind trajectory age and other factors. Also, most $\mathrm{PM}_{2.5}$ temporal changes within clusters were not significant at the $95 \%$ confidence level, but when combined into a larger data set that included all trajectories, the preponderance of declining $\mathrm{PM}_{2.5}$ levels indicates a significant negative trend.

In general, most trajectory clusters indicated declines in $\mathrm{PM}_{2.5}$ for 2007-2013. The exceptions were for clusters over eastern Kentucky (at $24 \mathrm{~h}$ upwind), central Georgia ( -12 and $-24 \mathrm{~h}$ ), northern Alabama ( $-12 \mathrm{~h}$ ), and northern Mississippi $(-24 \mathrm{~h})$. This analysis cannot assign importance to changes in specific aerosol components due to a lack of data, but given the relative contributions to $\mathrm{PM}_{2.5}$ we know that a trend must be associated with some combination of changes in sulfate and organic particle mass.

\section{Conclusions}

As stated in the beginning of this paper, the three objectives of this effort were to identify (1) trends in precursor emissions and air quality, (2) the degree of association between emissions and air quality trends, and (3) whether trends in meteorology influenced air quality trends. All three objectives were met - as summarized here - and the only poten- tial association between air quality and meteorological trends (objective 3) appears to be small.

The evidence indicates that annual average concentrations of $\mathrm{SO}_{2}$ have gone down by more than $60 \%$ since $1999-$ more rapidly since 2007 - although the decease appears to have leveled off recently. Concentrations of $\mathrm{PM}_{2.5}$ aerosol mass and all of its major chemical constituents have decreased by about $50 \%$ during the same period based on annual averages, but the annual trends of about -3 to $-4 \%$ per year have been driven mostly by reductions in the spring and summer season. The $\mathrm{PM}_{2.5}$ mass trend compares closely with the upper range in trends measured at other sites and in regions (especially the Ohio River valley) adjacent to Look Rock.

There have not been any significant changes in the modest diurnal patterns of major gaseous or particulate sulfate over the past decade. It should be noted that there are large year-to-year changes in most measured species concentrations which appear to be driven principally by changes in meteorology - rainfall, clouds, solar radiation, and temperature - and this is reflected by some of the seasonal associations identified between air quality and meteorology.

The more pronounced reduction in $\mathrm{SO}_{2}$ levels from 2007 to 2013 - compared with changes in sulfate levels over the same period $\left(85 \%\right.$ for $\mathrm{SO}_{2}$ and $58 \%$ for sulfate based on annual averages) - indicates that the spatial footprint of primary emissions of $\mathrm{SO}_{2}$ in the region is likely smaller than that for the largely secondary sulfate species. It appears that reductions in $\mathrm{SO}_{2}$ emissions have produced primary $\mathrm{SO}_{2}$ concentration reductions closer to the sources than those for sulfate, whose levels depend on atmospheric $\mathrm{SO}_{2}$-to-sulfate conversion processes that respond to changes in precursor emissions over a larger region.

Statistical modeling revealed that a $1 \mathrm{SD}(1 \sigma)$ decline in annual $\mathrm{SO}_{2}$ emissions in the emissions domain was associated with a $0.62 \sigma$ decline in annual-average ambient $\mathrm{SO}_{2}$. By comparison, a similar emission decline was associated with $0.97 \sigma$ decrease in spring and summer and a $0.76 \sigma$ decrease in winter. The $\mathrm{OC}$ association with $\mathrm{NO}_{x}$ emission was smaller, with a $1 \sigma$ drop in emissions linked to a $0.44 \sigma$ OC decrease in winter and $0.76 \sigma$ OC decrease in summer. Note that these statistical relations are all based on concentration variances and do not reflect absolute concentration responses to emissions. Changes in Look Rock air quality (1999-2013) appear to be influenced little by meteorological trends (unless a slow but steady decrease in winds somehow plays a role); instead, they are primarily controlled by changes in precursor emissions. Many of those changes have occurred nearby (as represented by the Look Rock emission domain defined here), but some of those changes are also due to emission changes farther upwind.

\section{The Supplement related to this article is available online at doi:10.5194/acp-15-9781-2015-supplement.}


Author contributions. R. Tanner was the primary architect of this study and performed most of the air quality data analysis. S. Bairai operated the Look Rock site and was primarily responsible for instrument maintenance, data quality assurance, and data archival. S. Mueller provided the meteorological, trajectory modeling, and statistical trend analyses. All three authors contributed to manuscript preparation.

Acknowledgements. We are grateful for the emission data provided by the Environmental Protection Agency and the meteorological and air quality data collected and archived by the National Park Service. We applaud the foresight of previous Tennessee Valley Authority management that funded the installation and operation of the Look Rock research station to enable tracking of long-term air quality trends in the valuable resource that is the Great Smoky Mountains. We also gratefully acknowledge the NOAA Air Resources Laboratory (ARL) for the provision of the HYSPLIT transport and dispersion model (http://www.ready.noaa.gov) used in this publication. This work was funded by the Electric Power Research Institute.

Edited by: A. Pozzer

\section{References}

Alley, F. C. and Ripperton, L. A.: The effect of temperature on photochemical oxidant production in a bench scale reaction system, J. Air Poll. Control Assoc., 11, 581-584, 1962.

Bae, M.-S., Schauer, J. J, DeMinter, J. T., Turner, J. R., Smith, D., and Cary, R. A.: Validation of a semi-continuous instrument for elemental carbon and organic carbon using a thermal-optical method, Atmos. Environ. 38, 2885-2893, 2004.

Bench, G., Fallon, S., Schichtel, B., Malm, W., and McDade, C.: Relative contributions of fossil and contemporary carbon sources to $\mathrm{PM}_{2.5}$ aerosols at nine Interagency Monitoring for Protection of Visual Environments (IMPROVE) network sites, J. Geophys. Res., 112, D10205, doi:10.1029/2006JD007708, 2007.

Birch, M. E. and Cary, R. A.: Elemental carbon-based method for monitoring occupational exposure to particulate diesel exhaust, Aerosol Sci. Technol., 25, 221-241, 1996.

Brewer, P. and Moore, T.: Source contributions to visibility impairment in the southeastern and western United States, J. Air Waste Ma., 59, 1070-1081, doi:10.3155/1047-3289.59.9.1070, 2009.

Budisulistiorini, S. H., Li, X., Bairai, S. T., Renfro, J., Liu, Y., Liu, Y. J., McKinney, K. A., Martin, S. T., McNeill, V. F., Pye, H. O. T., Nenes, A., Neff, M. E., Stone, E. A., Mueller, S., Knote, C., Shaw, S. L., Zhang, Z., Gold, A., and Surratt, J. D.: Examining the effects of anthropogenic emissions on isoprenederived secondary organic aerosol formation during the 2013 Southern Oxidant and Aerosol Study (SOAS) at the Look Rock, Tennessee ground site, Atmos. Chem. Phys., 15, 8871-8888, doi:10.5194/acp-15-8871-2015, 2015.

Cai, M., Schwartz, J. S., Robinson, R. B., Moore, S. E., and Kulp, M. A.: Long-term annual and seasonal patterns of acidic deposition and stream water quality in a Great Smoky Mountains highelevation watershed, Water, Air, \& Soil Poll. 219, 547-562, 2011.
Chalbot, M.-C., McElroy, B., and Kavouras, I. G.: Sources, trends and regional impacts of fine particulate matter in southern Mississippi valley: significance of emissions from sources in the Gulf of Mexico coast, Atmos. Chem. Phys., 13, 3721-3732, doi:10.5194/acp-13-3721-2013, 2013.

Cheng, M.-D. and Tanner, R. L.: Characterization of ultrafine and fine particles at a site near the Great Smoky Mountains National Park, Atmos. Environ. 36, 5795-5806, 2002.

Chow, J. C., Watson, J. G., Pritchett, L. C., Pierson, W. R., Frazier, C. A., and Purcell, R. G.: The DRI thermal/optical analysis system: description, evaluation, and application in U.S. air quality studies, Atmos. Environ., 27A, 1185-1201, 1993.

Cooper O. R., Parrish D. D., Ziemke J., Balashov N. V., Cupeiro M., Galbally, I. E., Gilge, S., Horowitz, L., Jensen, N. R., Lamarque, J.-F., Naik, V., Oltmans, S. J., Schwab, J., Shindell, D. T., Thompson, A. M., Thouret, V., Wang, Y., and Zbinden, R. M.: Global distribution and trends of tropospheric ozone: An observation-based review, Elem. Sci. Anth. 2, doi:10.12952/journal.elementa.000029, 2014.

Day, D. E., Malm, W. C., and Ames, R. B.: Southeastern Aerosol and Visibility Study (SEAVS): Final Report, Cooperative Institute for Resarch in the Atmosphere, Colorado State University, Fort Collins, CO, USA, available at: http://vista.cira.colostate.edu/improve/studies/SEAVS/ Reports/FinalReport/seavsfinalreport.htm (last access: $26 \mathrm{Au}-$ gust 2015), 1996.

Draxler, R. R.: HYSPLIT4 user's guide. NOAA Tech. Memo. ERL ARL-230, NOAA Air Resources Laboratory, Silver Spring, MD, USA, 1999.

Draxler, R. R. and Hess, G. D.: An overview of the HYSPLIT_4 modeling system of trajectories, dispersion, and deposition, Aust. Meteor. Mag., 47, 295-308, 1998.

Draxler, R. R. and Rolph, G. D.: HYSPLIT (HYbrid Single-Particle Lagrangian Integrated Trajectory) Model, NOAA Air Resources Laboratory, Silver Spring, MD, USA, http://ready.arl.noaa.gov/ HYSPLIT.php (last access: 26 August 2015), 2014.

Hallquist, M., Wenger, J. C., Baltensperger, U., Rudich, Y., Simpson, D., Claeys, M., Dommen, J., Donahue, N. M., George, C., Goldstein, A. H., Hamilton, J. F., Herrmann, H., Hoffmann, T., Iinuma, Y., Jang, M., Jenkin, M. E., Jimenez, J. L., Kiendler-Scharr, A., Maenhaut, W., McFiggans, G., Mentel, Th. F., Monod, A., Prévôt, A. S. H., Seinfeld, J. H., Surratt, J. D., Szmigielski, R., and Wildt, J.: The formation, properties and impact of secondary organic aerosol: current and emerging issues, Atmos. Chem. Phys., 9, 5155-5236, doi:10.5194/acp-9-51552009, 2009.

Hand, J. L.: Spatial and Seasonal Patterns and Temporal Variability of Haze and its Constituents in the United States Report V, Cooperative Institute for Research in the Atmosphere, Colorado State University, Fort Collins, CO, USA, ISSN 0737-5352-87, available at: http://vista.cira.colostate.edu/improve/Publications/ Reports/2011/2011.htm (last access: 26 August 2015), 2011.

Hand, J. L., Schichtel, B. A., Malm, W. C., and Pitchford, M. L.: Particulate sulfate ion concentration and $\mathrm{SO}_{2}$ emission trends in the United States from the early 1990s through 2010, Atmos. Chem. Phys., 12, 10353-10365, doi:10.5194/acp-1210353-2012, 2012.

Hoyle, C. R., Boy, M., Donahue, N. M., Fry, J. L., Glasius, M., Guenther, A., Hallar, A. G., Huff Hartz, K., Petters, M. D., Petäjä, 
T., Rosenoern, T., and Sullivan, A. P.: A review of the anthropogenic influence on biogenic secondary organic aerosol, Atmos. Chem. Phys., 11, 321-343, doi:10.5194/acp-11-321-2011, 2011.

Lamb, B., Gay, D., Westberg, H., and Pierce, T.: A biogenic hydrocarbon emission inventory for the U.S.A. using a simple forest canopy model, Atmos. Environ., 11, 1673-1690, 1993.

Malm, W. C., Schichtel, B. A., and Pitchford, M. L.: Uncertainties in $\mathrm{PM}_{2.5}$ gravimetric and speciation measurements and what we can learn from them, J. Air Waste Ma., 61, 1131-1149, 2011.

Milton, J.: Why winds are slowing, Nature News, available at: www. nature.com/news/2010/101017/full/news.2010.543.html (last access: 26 August 2015), 2010.

Olszyna, K. J., Bairai, S. T., and Tanner, R. L.: Effect of ambient $\mathrm{NH}_{3}$ levels on $\mathrm{PM}_{2.5}$ composition in the Great Smoky Mountains National Park, Atmos. Environ., 39, 4593-4606, 2005.

Preisendorfer, R. W.: Principal Component Analysis in Meteorology and Oceanography, Chapter 2, Elsevier, Oxford, UK, 11-15, 1988.

Pryor, S. C. and Ledolter, J.: Addendum to "Wind speed trends over the contiguous United States”, J. Geophys. Res., 115, D10103, doi:10.1029/2009JD013281, 2010.

Pryor, S. C., Barthelmie, R. J., Young, D. T., Takle, E. S., Arritt, R. W., Flory, D., Gutowski Jr., W. J., Nunes, A., and Roads, J.: Wind speed trends over the contiguous United States, J. Geophys. Res., 114, D14105, doi:10.1029/2008JD011416, 2009.

Seinfeld, J. H., and Pandis, S. N.: Atmospheric Chemistry and Physics, Chapter 3, John Wiley \& Sons, Inc., New York, USA, 1998.

Shilling, J. E., Zaveri, R. A., Fast, J. D., Kleinman, L., Alexander, M. L., Canagaratna, M. R., Fortner, E., Hubbe, J. M., Jayne, J. T., Sedlacek, A., Setyan, A., Springston, S., Worsnop, D. R., and Zhang, Q.: Enhanced SOA formation from mixed anthropogenic and biogenic emissions during the CARES campaign, Atmos. Chem. Phys., 13, 2091-2113, doi:10.5194/acp-13-20912013, 2013.

Simon, H., Reff, A., Wells, B., Xing, J., and Frank, N.: Ozone trends across the United States over a period of decreasing $\mathrm{NO}_{x}$ and VOC Emissions, Environ. Sci. Technol. 49, 186-195, doi:10.1021/es504514z, 2015.

Stuiver, M. and Polach, H. A.: Reporting of C-14 data - Discussion, Radiocarbon, 19, 355-363, 1977.

Surratt, J. D., Chan, A. W. H., Eddingsaas, N. C., Chan, C., Loza, C. L., Kwan, A. J., Hersey, S. P., Flagan, R. C., Wennberg, P. O., and Seinfeld, J. H.: Reactive intermediates revealed in secondary organic aerosol formation from isoprene, P. Natl. Acad. Sci. USA, 107, 6640-6645, 2010.

Tanner, R. L. and Gaffney, J. S.: Carbon isotopes as tracers of biogenic and anthropogenic carbon transport in the atmosphere, Fossil Fuels Utilization: Environmental Concerns, edited by: Markuszewski, R. and Blaustein, B. D., American Chemical Society Symposium Series No. 319, American Chemical Society, Washington, D.C., USA, 267-276, 1986.
Tanner, R. L., Parkhurst, W. J., and McNichol, A. P.: Fossil sources of $\mathrm{PM}_{2.5}$ aerosol carbon based on ${ }^{14} \mathrm{C}$ measurements, Aerosol Sci. Tech., 38, 133-139, 2004a.

Tanner, R. L., Parkhurst, W. J., Valente, M. L., and Phillips, W. D.: Regional composition of $\mathrm{PM}_{2.5}$ aerosols measured at urban, rural and "background" sites in the Tennessee Valley, Atmos. Environ., 38, 3143-3153, 2004b.

Tanner, R. L., Bairai, S. T., Olszyna, K. J., Valente, M. L., and Valente, R. J.: Diurnal patterns in $\mathrm{PM}_{2.5}$ mass and composition at a background, complex terrain site, Atmos. Environ., 39, 3865 3875, 2005.

U.S. Energy Information Administration: Annual Energy Outlook 2014 with Projections to 2040. Department of Energy, DOE/EIA-0383(2014), available at: www.eia.gov/forecasts/aeo/ pdf/0383(2014).pdf (last access: 26 August 2015), 2014.

U.S. National Oceanic and Atmospheric Administration (NOAA): Southeast Nexus (SENEX): studying the interactions between natural and anthropogenic emissions at the nexus of air quality and climate change, NOAA, Boulder, CO, USA, available at: www.esrl.noaa.gov/csd/projects/senex (last access: 26 August 2015), 2013

U.S. National Park Service: Air quality in national parks: trends (2000-2009) and conditions (2005-2009), Air Resources Division Natural Resource Report, NPS/NRSS/ARD/NRR 2013/683, 2013.

Weber, R. J., Sullivan, A. P., Peltier, R. E., Russell, A., Yan, B., Zheng, M., de Gouw, J., Warneke, C., Brock, C., Holloway, J. S., Atlas, E. L., and Edgerton, E.: A study of secondary organic aerosol formation in the anthropogenicinfluenced southeastern United States. J. Geophys. Res., 112, D13302, doi:10.1029/2007JD008408, 2007.

Wilks, D. S.: Statistical Methods in the Atmospheric Sciences, Chapter 14, Academic Press, Boston, USA, 549-562, 2006.

Zhang, Y. L., Perron, N., Ciobanu, V. G., Zotter, P., Minguillón, M. C., Wacker, L., Prévôt, A. S. H., Baltensperger, U., and Szidat, S.: On the isolation of OC and EC and the optimal strategy of radiocarbon-based source apportionment of carbonaceous aerosols, Atmos. Chem. Phys., 12, 10841-10856, doi:10.5194/acp-12-10841-2012, 2012.

Zotter, P., El-Haddad, I., Zhang, Y., Hayes, P. L., Zhang, X., Lin, Y.-H., Wacker, L., Schnelle-Kreis, J., Abbaszade, G., Zimmermann, R., Surratt, J. D., Weber, R., Jimenez, J. L., Szidat, S., Baltensperger, U., and Prévôt, A. S. H.: Diurnal cycle of fossil and nonfossil carbon using radiocarbon analyses during CalNex, J. Geophys. Res., 119, 6818-6835, doi:10.1002/2013JD021114, 2014. 